\title{
Temporal and vertical variability in picophytoplankton primary productivity in the North Pacific Subtropical Gyre
}

\author{
Yoshimi M. Riii ${ }^{1,2, *}$, David M. Karl ${ }^{1,2}$, Matthew J. Church ${ }^{1,2,3}$ \\ ${ }^{1}$ Department of Oceanography, University of Hawai'i at Mānoa, Honolulu, HI 96822, USA \\ ${ }^{2}$ Daniel K. Inouye Center for Microbial Oceanography: Research and Education, University of Hawai'i at Mãnoa, Honolulu, \\ HI 96822, USA \\ ${ }^{3}$ Present address: Flathead Lake Biological Station, University of Montana, Polson, MT 59860, USA
}

ABSTRACT: Picophytoplankton $(\leq 3 \mu \mathrm{m})$ are major contributors to plankton biomass and primary productivity in the subtropical oceans. We examined vertical and temporal variability of picophytoplankton primary productivity at near-monthly time scales (May 2012May 2013) in the North Pacific Subtropical Gyre (NPSG) based on filter size-fractionated and flow cytometric sorting of radiolabeled $\left({ }^{14} \mathrm{C}\right)$ picoplankton cells. Primary productivity by picophytoplankton comprised $\sim 68$ to $83 \%$ of total $(>0.2 \mu \mathrm{m})$ particulate ${ }^{14} \mathrm{C}$-based productivity, and was lowest between September and December and highest between March and August. Group-specific rates of production by Prochlorococcus, Synechococcus, and photosynthetic picoeukaryotes (PPE) averaged $\sim 39, \sim 2$, and $\sim 11 \%$ of the total ${ }^{14} \mathrm{C}$-productivity, respectively. Average cellspecific rates of production by PPE (15.2 fmol C cell ${ }^{-1}$ $\mathrm{d}^{-1}$ ) were 25 - to 90 -fold greater than Prochlorococcus (0.36 fmol C cell ${ }^{-1} \mathrm{~d}^{-1}$ ) and Synechococcus (1.56 fmol C cell $\left.{ }^{-1} \mathrm{~d}^{-1}\right)$. Prochlorococcus dominated (61-78\%) the summed picophytoplankton biomass, while PPE and Synechococcus contributed $21-36 \%$ and 2-8\%, respectively. Rates of production normalized to biomass were nearly equivalent amongst Prochlorococcus, Synechococcus, and PPE, averaging 0.6, 0.5, and $0.4 \mathrm{~d}^{-1}$, respectively. Over our study period, Prochlorococcus and PPE production varied 4- to 5-fold, while biomass varied $\sim 3$-fold. In contrast, Synechococcus production varied $\sim 30$-fold, with peak rates in March 2013 accompanied by $~ 13$-fold increase in biomass. Combined, our results provide evidence for rapid growth by picophytoplankton in this persistently lownutrient ecosystem, highlighting the importance of cell loss processes responsible for mediating organic matter cycling in the euphotic zone of the NPSG.

\footnotetext{
*Corresponding author: shimi@hawaii.edu
}

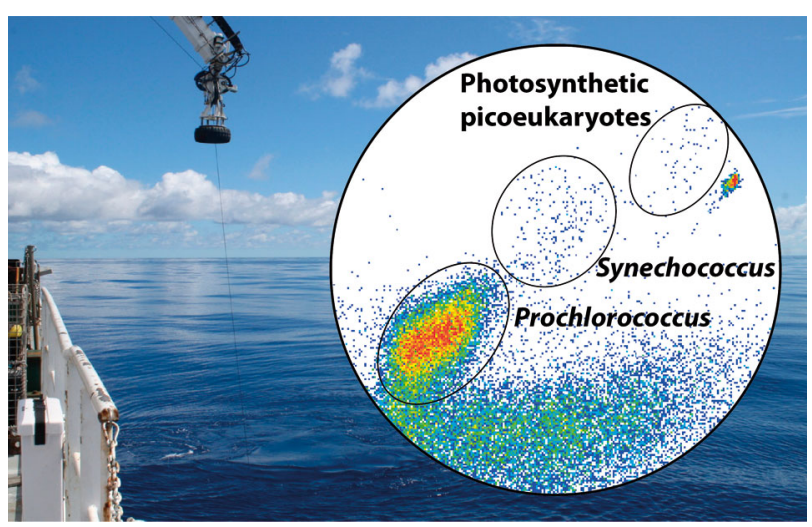

Flow cytometric sorting of ${ }^{14} \mathrm{C}$-radiolabeled cells allowed quantification of primary productivity by specific picophytoplankton in the North Pacific Subtropical Gyre. Images: Flow cytogram and shipboard operations at Station ALOHA

(Photo \& diagram: Y. Rii)

KEY WORDS: Picoplankton $\cdot{ }^{14} \mathrm{C}$ primary production • Picophytoplankton · Picoeukaryotes $\cdot$ Prochlorococcus . Synechococcus $\cdot$ Flow cytometry $\cdot$ Time series $\cdot$ North Pacific

\section{INTRODUCTION}

Picophytoplankton $(\leq 3 \mu \mathrm{m})$ are dominant contributors to plankton biomass and net global productivity, particularly in the oligotrophic subtropical ocean gyres (Sieburth et al. 1978, Marañón et al. 2001, Carr et al. 2006). In the North Pacific Subtropical Gyre (NPSG), one of the largest ocean ecosystems on Earth (Sver-

() The authors 2016. Open Access under Creative Commons by Attribution Licence. Use, distribution and reproduction are unrestricted. Authors and original publication must be credited. 
drup et al. 1946), persistent thermal stratification of the upper ocean and a relatively deep, permanent pycnocline largely prevent nutrient-enriched deep waters from penetrating the euphotic zone (Eppley et al. 1973, Karl \& Lukas 1996). The combination of stratification and perennially high photosynthetically active radiation (PAR) promotes active consumption of available nutrients by phytoplankton, resulting in persistently low concentrations of inorganic nutrients throughout the upper ocean. As a result, a large fraction of primary productivity appears to be sustained by the rapid recycling of nutrients through microbial food webs (Karl 2002).

A diverse assemblage of picoplankton, including photosynthetic picoeukaryotes (PPE) and cyanobacteria belonging to the genera Prochlorococcus and Synechococcus, dominate (60-90\%) phytoplankton biomass and account for $>70 \%$ of net primary production in the NPSG (Campbell \& Vaulot 1993, Vaulot et al. 1995, Li et al. 2011). The significant contributions of picophytoplankton to biomass and primary production appear linked to efficient nutrient acquisition and light-harvesting capabilities (Takahashi \& Bienfang 1983, Raven 1986, Chisholm 1992, Raven 1998). Amongst the picophytoplankton, cellular abundances of Prochlorococcus are typically orders of magnitude greater than those of Synechococcus or PPE in the NPSG, and past studies have largely focused on understanding the controls on cyanobacterial growth rather than their eukaryotic counterparts (e.g. Campbell \& Vaulot 1993, Campbell et al. 1994, Liu et al. 1995, Björkman et al. 2015). However, studies from the subtropical Atlantic Ocean have reported high cell-specific rates of ${ }^{14} \mathrm{C}$ primary production by PPE, making them potentially significant contributors to carbon fixation (Li 1994, Jardillier et al. 2010). Moreover, studies in the North Atlantic indicated that a large fraction of PPE growth may be supported through assimilation of nitrate (Fawcett et al. 2011, 2014), making these picoplanktonic organisms potentially important contributors to new production.

Since 1988, the Hawaii Ocean Time-series (HOT) program has measured a suite of properties and processes to characterize ocean physics and biogeochemistry on near-monthly time scales at Station ALOHA $\left(22.75^{\circ} \mathrm{N}, 158^{\circ} \mathrm{W}\right)$, a site representative of the NPSG (Karl \& Lukas 1996). The resulting measurements have proven invaluable for characterizing temporal dynamics of bioelemental stocks and fluxes in this ecosystem. For example, the HOT program measurements of ${ }^{14} \mathrm{C}$-based primary productivity reveal seasonal variations that co-vary with changes in solar radiation (Karl \& Church 2014). Superimposed on this seasonal dynamic are annually recurring summertime phytoplankton blooms, whose occurrences are often linked to episodic mesoscale events such as eddies (Dore et al. 2008, Church et al. 2009) and appear to be large contributors to particulate carbon export to the deep sea (Karl et al. 2012). In addition, temporal variations in light appear to have a significant impact on the dynamics of nutrient drawdown and subsequent carbon cycling in the lower euphotic zone. For example, decreased light flux during the winter months appears to prevent photosynthetic plankton from utilizing available nutrients in the lower euphotic zone, resulting in the accumulation of nutrients (upwards of $36 \mathrm{mmol} \mathrm{m}^{-2}$ nitrate, Letelier et al. 2004). However, once sufficient light becomes available to these dimly lit waters in the spring, phytoplankton biomass increases, coincident with nitrate drawdown (Letelier et al. 2004). To date, there is limited information on the contributions of major groups of photosynthetic organisms to temporal variations in primary productivity at Station ALOHA, or on how time-varying changes in the upper ocean habitat influence phytoplankton production and growth in this ecosystem.

Examination of picoplankton contributions to primary productivity has been typically conducted through the size-partitioning of productivity using a range of filter pore sizes to separate plankton biomass. In addition, studies have characterized the specific contributions of picoplankton assemblages to rates of primary production through particle size distributions (Barone et al. 2015, White et al. 2015), specific photosynthetic pigment-based labeling (Goericke \& Welschmeyer 1993, Pinckney et al. 1996), and flow cytometric sorting of radiolabeled cells (Li 1994, Jardillier et al. 2010, Björkman et al. 2015, Rii et al. 2016). In the current study, we relied on combined size-fractionated measurements of ${ }^{14} \mathrm{C}$-bicarbonate assimilation and flow cytometric sorting of ${ }^{14} \mathrm{C}$ labeled picoplankton populations to examine vertical and temporal patterns in carbon fixation on 11 cruises to Station ALOHA spanning a 1 yr period. The resulting measurements provided quantitative information on the contributions of dominant groups of picophytoplankton to carbon fixation in this persistently oligotrophic ecosystem.

\section{MATERIALS AND METHODS}

\section{Sample collection}

Seawater was collected in 121 polyvinylchloride bottles affixed to a rosette sampler equipped with 
Table 1. Sampling dates, variability in light, mixed layer depths (mean $\pm \mathrm{SD}$ ), and depth-integrated (0-125 m) inventories of chlorophyll a (chl a), Prochlorococcus (PRO), Synechococcus (SYN), and photosynthetic picoeukaryotes (PPE) measured during this study. H: Hawaii Ocean Time-series (HOT) cruise; HD: Center for Microbial Oceanography: Research and Education cruise HOE-DYLAN V; PAR: photosynthetically active radiation, nd: no data

\begin{tabular}{|c|c|c|c|c|c|c|c|c|}
\hline Cruise & (mo & $\begin{array}{l}\text { Incident PAR } \\
\text { nol quanta } \mathrm{m}^{-2} \mathrm{~d}^{-1} \text { ) }\end{array}$ & $\begin{array}{l}\text { Depth of } 1 \% \text { of } \\
\text { incident PAR }(\mathrm{m})\end{array}$ & $\begin{array}{l}\text { Mixed layer } \\
\text { depth }(\mathrm{m})\end{array}$ & $\begin{array}{c}\mathrm{Chl} \mathrm{a} \\
\left(\mathrm{mg} \mathrm{m}^{-2}\right)\end{array}$ & $\begin{array}{c}\text { PRO } \\
\left(\times 10^{11} \text { cells m }{ }^{-2}\right)\end{array}$ & $\begin{array}{c}\text { SYN } \\
\left(\times 10^{11} \text { cells m }^{-2}\right)\end{array}$ & $\begin{array}{c}\text { PPE } \\
\left(\times 10^{11} \text { cells m}^{-2}\right)\end{array}$ \\
\hline H242 & 30 May 2012 & 48.42 & nd & $36 \pm 6$ & 14.59 & 214.52 & 1.44 & 1.17 \\
\hline H243 & 25 Jun 2012 & 42.76 & 118 & $73 \pm 8$ & 14.74 & 201.63 & 1.38 & 1.65 \\
\hline HD5 & 12 Jul 2012 & 44.34 & nd & $58 \pm 13$ & 18.04 & 208.35 & 1.31 & 1.36 \\
\hline H245 & 17 Aug 2012 & nd & 110 & $34 \pm 6$ & 14.07 & 256.74 & 1.96 & 1.34 \\
\hline H246 & 14 Sep 2012 & 41.67 & 109 & $59 \pm 7$ & 15.16 & 180.98 & 0.97 & 1.26 \\
\hline $\mathrm{H} 247$ & 07 Oct 2012 & 35.83 & 106 & $60 \pm 8$ & 15.36 & 208.80 & 1.63 & 0.90 \\
\hline H248 & 03 Dec 2012 & 15.17 & 109 & $92 \pm 11$ & 19.92 & 232.71 & 0.89 & 1.22 \\
\hline H249 & 12 Feb 2013 & 24.06 & 109 & $111 \pm 37$ & 13.01 & 275.34 & 3.47 & 1.95 \\
\hline $\mathrm{H} 250$ & 06 Mar 2013 & 38.99 & 117 & $126 \pm 45$ & 22.24 & 226.19 & 4.57 & 1.88 \\
\hline H251 & 05 Apr 2013 & 38.17 & 115 & $77 \pm 28$ & 21.24 & 275.61 & 2.80 & 1.86 \\
\hline H252 & 17 May 2013 & nd & 116 & $39 \pm 10$ & 17.14 & 285.85 & 1.60 & 1.73 \\
\hline
\end{tabular}

a Sea-Bird 911+ conductivity, temperature, and pressure sensors. Size-fractionated and group-specific rates of ${ }^{14} \mathrm{C}$-assimilation were measured between May 2012 and May 2013 on 10 HOT program cruises (H242-H243, H245-H252) and 1 Center for Microbial Oceanography: Research and Education (CMORE) research cruise (termed HOE-DYLAN V, or HD5) to Station ALOHA (Table 1).

\section{In situ measurements of ${ }^{14} \mathrm{C}$-bicarbonate assimilation}

Rates of size-fractionated ( $>3$ and $0.2-3 \mu \mathrm{m}$ ) and group-specific particulate ${ }^{14} \mathrm{C}$-based primary production were measured at 6 discrete depths $(5,25$, $45,75,100$, and $125 \mathrm{~m}$ ) throughout the euphotic zone. These depths were chosen to complement the ongoing, long-term HOT program measurements of ${ }^{14} \mathrm{C}$-based primary production (Karl \& Church 2014). Seawater samples from each depth were subsampled into triplicate $30 \mathrm{ml}$ polycarbonate centrifuge tubes (Nalgene ${ }^{\mathrm{TM}}$ ) from a pre-dawn cast, inoculated under subdued light with $70 \mu \mathrm{l}$ of $\mathrm{NaH}^{14} \mathrm{CO}_{3}$ (final activity = $\sim 0.14 \mathrm{MBq} \mathrm{ml}^{-1}$; MP Biomedicals $17441 \mathrm{H}$ ), then incubated over the full photoperiod $(\sim 12-14 \mathrm{~h})$ in white mesh bags affixed to a floating in situ array at the corresponding depths where the water was collected.

At the end of the incubation period (after sundown), each polycarbonate tube was sampled for size-fractionated and group-specific rates of ${ }^{14} \mathrm{C}$ primary productivity. Aliquots $(25 \mu \mathrm{l})$ were subsampled from each tube and stored in $20 \mathrm{ml}$ glass scintillation vials containing $500 \mu \mathrm{l}$ of $\beta$-phenylethylamine to determine the total activity of ${ }^{14} \mathrm{C}$ added to each sample. Next, $5 \mathrm{ml}$ of each sample were preserved in cryotubes containing $30 \mu \mathrm{l}$ of $16 \%$ (final concentration $0.24 \% \mathrm{w} / \mathrm{v}$ ) microscopy-grade paraformaldehyde (PFA, Alfa Aesar 43368), flash-frozen in liquid nitrogen, and stored at $-80^{\circ} \mathrm{C}$ for subsequent flow cytometric sorting. The remaining sample volume $(\sim 25 \mathrm{ml})$ was vacuum-filtered first onto a $25 \mathrm{~mm}$ diameter, $3 \mu \mathrm{m}$ pore size polycarbonate membrane (Millipore Isopore ${ }^{\mathrm{TM}}$ ), and then the filtrate was vacuum-filtered onto a $25 \mathrm{~mm}$ diameter, $0.2 \mu \mathrm{m}$ pore size polycarbonate membrane filter (GE Osmonics). After filtration, each filter was placed into a $20 \mathrm{ml}$ glass scintillation vial and stored at $-20^{\circ} \mathrm{C}$ until analyzed back at the shore-based laboratory. Upon return to shore, vials were uncapped, $1 \mathrm{ml}$ of $2 \mathrm{M}$ hydrochloric acid was added to each filter, and vials were vented for at least $24 \mathrm{~h}$ to remove remaining inorganic ${ }^{14} \mathrm{C}$. After venting, $10 \mathrm{ml}$ of Ultima Gold liquid scintillation cocktail were added to each vial, and vials were placed in a liquid scintillation counter (Packard TRICarb 4640) for the determination of ${ }^{14} \mathrm{C}$ activities. In this study, ${ }^{14} \mathrm{C}$ primary productivity measured on the $3 \mu \mathrm{m}$ membrane is termed the ' $>3 \mu \mathrm{m}$ ' fraction, and the productivity measured on the $0.2 \mu \mathrm{m}$ membrane (hence representing $0.2-3 \mu \mathrm{m}$ ) is referred to as the 'picophytoplankton' fraction. We refer to the sum of the $>3 \mu \mathrm{m}$ and the picophytoplankton fractions as the 'total' ${ }^{14} \mathrm{C}$ primary productivity.

Group-specific rates of ${ }^{14} \mathrm{C}$-assimilation by Prochlorococcus, Synechococcus, and PPE were determined by measuring the amount of ${ }^{14} \mathrm{C}$ assimilated into populations sorted using the $\mathrm{BD}$ Influx ${ }^{\mathrm{TM}}$ (100 $\mu \mathrm{m}$ nozzle tip, 1X BioSure ${ }^{\circledR}$ sheath solution). 
Calibration of the number of cells sorted was conducted at the beginning of each sorting session; a known number of fluorescent microspherical beads ( $1 \mu \mathrm{m}$, Fluoresbrite, Polysciences) were gated through the data acquisition software Spigot, sorted onto a slide, and checked for accuracy under the microscope. The '1.0 drop purity' setting in the Spigot software was used as a conservative way of ensuring accuracy of the types of cells sorted into two $6.5 \mathrm{ml}$ HDPE scintillation vials with the ' 2 tube sort' setting. Beads were included with the samples for size reference, and 200 to 4000 beads were sorted for the determination of background levels of radioactivity (both organic ${ }^{14} \mathrm{C}$ in the seawater and ${ }^{14} \mathrm{C}$ absorbed to the beads). Picophytoplankton cells were triggered on forward scatter (FSC) and enumerated based on FSC and side scatter, chlorophyll-based red fluorescence (692 $\pm 20 \mathrm{~nm})$, and phycoerythrin-based orange fluorescence $(585 \pm 20 \mathrm{~nm})$ following excitation with 2 lasers, $488 \mathrm{~nm}(200 \mathrm{~mW})$ and $457 \mathrm{~nm}$ (300 mW), through separate pinholes.

Prochlorococcus and Synechococcus cells were identified based on red fluorescence signals against FSC, then further gated by side scatter and orange fluorescence. PPE cells were distinguished based on high red fluorescence and low orange fluorescence in reference to FSC, and excluding Prochlorococcus and Synechococcus gates. For each picophytoplankton group, the number of cells sorted ranged from 25000 for Prochlorococcus, 100 to 10000 for Synechococcus, and 360 to 35000 for PPE. Linearity between cells sorted and radioactivity was checked regularly. We were unable to sort a sufficient number of Synechococcus cells for detection of radioactivity at $100 \mathrm{~m}$ for August, October, and December 2012, and at $125 \mathrm{~m}$ for all months except in March 2013. After sorting, $200 \mu \mathrm{l}$ of $2 \mathrm{M}$ hydrochloric acid were added to each vial containing the cells, and vials were vented for $48 \mathrm{~h}$, followed by addition of $4 \mathrm{ml}$ of Ultima Gold liquid scintillation cocktail. After $1 \mathrm{~h}$, the vials were placed in a liquid scintillation counter (Packard TRI-Carb 4640) for the determination of ${ }^{14} \mathrm{C}$ activities (30 min count time per sample). The resulting radioactivities were converted to average cellspecific and group-specific ${ }^{14} \mathrm{C}$-assimilation rates based on total radioactivity added to the incubations, measured dissolved inorganic carbon concentrations (from the HOT Data Organization and Graphical System, http://hahana.soest.hawaii.edu/hot/hot-dogs), a correction for preferential assimilation of ${ }^{12} \mathrm{C}$ relative to ${ }^{14} \mathrm{C}$ (Steemann Nielsen 1952), the number of cells sorted, and the measured cell abundances (see next section).

\section{Picophytoplankton cell abundance and biomass calculations}

Seawater $(2 \mathrm{ml})$ was collected into cryotubes (Corning) containing a final concentration of $0.24 \%$ (w/v) microscopy-grade PFA. Cryotubes were stored at room temperature for $15 \mathrm{~min}$ in the dark, then flash-frozen in liquid nitrogen and stored at $-80^{\circ} \mathrm{C}$ until analysis. Each picophytoplankton population was distinguished with the same fluorescence and scatter parameters described above, and cell counts were determined using the data analysis software FlowJo 10.0.7.

Flow cytometric determinations of FSC were used to estimate cell size using an empirically derived relationship between measured FSC and epifluorescence microscopy-derived estimates of cell diameters. Laboratory cultures of the picocyanobacteria Prochlorococcus spp. (MIT 9301) and 5 isolates of PPE from Station ALOHA and Kāne'ohe Bay, O'ahu, Hawai'i (Micromonas spp., KB-FL13; raphidophyte, KB-FL10; Pelagomonas spp., AL-D101-P; chlorarachniophyte, AL-FL05; and Chrysochromulina spp., ALTEMP-12), were used to determine an FSC-to-cell size relationship with flow cytometer settings identical to sorting and counting. The cells were first identified based on autofluorescence using epifluorescence microscopy on a Nikon Eclipse 90i using a chlorophyll-specific filter set $(480 / 30 \mathrm{~nm}$ excitation, $600 \mathrm{~nm}$ emission), and digital images of the cells (magnified 1000×) were captured under bright-field illumination. Cell diameters were estimated from the imaged microscopy fields using a calibrated length tool in the image analysis software NIS Elements AR 3.22.11. FSC measurements were linearly normalized to $1 \mu \mathrm{m}$ beads analyzed concurrently with the cultivated isolates (Table A1 in the Appendix). An empirically derived power equation (cell diameter $\left.[\mu \mathrm{m}]=0.3071 \times[\mathrm{FSC}]^{0.2857}, \mathrm{R}^{2}=0.99\right)$ was used to estimate the mean cell diameters of Prochlorococcus, Synechococcus, and PPE cells sorted in this study (Table A2 in the Appendix). Cell biovolume was calculated assuming a spherical shape, and carbon biomass was estimated using 2 approaches: first using the biovolume-carbon conversion factor $237 \mathrm{fg} \mathrm{C}$ $\mu \mathrm{m}^{-3}$ (Worden et al. 2004), and the second using the empirical function described by Eppley et al. (1970) and applied by Shalapyonok et al. (2001). Both of these approaches yielded comparable estimates of cell biomass; hence, for the current study, we used the biovolume-carbon conversion factor (237 fg C $\mu^{-3}$ ) for subsequent estimates of photosynthetic picoplankton biomass. 


\section{Mixing, light, nutrients, and pigments}

Physical and biogeochemical characteristics of the water column were obtained as part of the nearmonthly HOT program core measurements at Station ALOHA (http://hahana.soest.hawaii.edu/hot/ hot-dogs/). The mixed layer depth for each research cruise was defined as the depth where a 0.125 potential density offset was observed relative to the nearsurface ocean waters ( $<5 \mathrm{~m}$; Brainerd \& Gregg 1995). A HyperPro radiometer (Satlantic) was used to collect daily vertical profiles of midday downwelling PAR, and coincident measurements of incident PAR were collected using a deckboard radiometer (Satlantic). Together, these measurements were used to compute the downwelling PAR attenuation coefficient $\left(\mathrm{K}_{\mathrm{PAR}}\right)$. Daily-integrated PAR (400 to $700 \mathrm{~nm}$ ) at the sea surface was measured with a LI-COR LI-1000 cosine collector and data logger. The flux of downwelling PAR at the discrete depths where productivity measurements were conducted was derived from measured $\mathrm{K}_{\mathrm{PAR}}$ values and the daily-integrated incident PAR measurements. For the determination of nitrate + nitrite $\left(\mathrm{NO}_{3}{ }^{-}+\mathrm{NO}_{2}{ }^{-}\right)$in the upper $125 \mathrm{~m}$, seawater samples collected at each depth were analyzed in triplicate following a high-sensitivity chemiluminescent method (Garside 1982, Dore \& Karl 1996). HOT program measurements of high performance liquid chromatography (HPLC)-derived chl a were obtained following the protocols of Bidigare et al. (2005).

\section{Data analyses}

For statistical analyses, data sets were tested for normality using the Shapiro-Wilk test (Royston 1982) and quantile-quantile plots, and those that rejected the null hypothesis $(\mathrm{p}>0.05)$ were $\log _{10}$-transformed. Comparisons between 2 sets of normally distributed samples were conducted with Welch's t-test (Welch 1951). When $\log _{10}$ transformation was not successful in attaining normality, non-parametric methods (Kruskal-Wallis test, Hollander \& Wolfe 1973) were used to test for significant differences between data sets.

The euphotic zone at Station ALOHA typically extends below the penetration depth of the $1 \%$ surface PAR, which oscillates between $\sim 85$ and $125 \mathrm{~m}$. For this study, examined parameters were depthintegrated to $125 \mathrm{~m}$, capturing the region of the ocean where the majority of the photosynthetic biomass resides and rates of productivity are greatest (e.g. rates of ${ }^{14} \mathrm{C}$ primary production below $125 \mathrm{~m}$ contribute $<3 \%$ to the $0-175 \mathrm{~m}$ integrated production, http://hahana.soest.hawaii.edu/hot/hot-dogs/). In addition, we examined temporal dynamics of picophytoplankton productivity in the 'upper' $(0-45 \mathrm{~m})$ and the 'lower' (75-125 m) regions of the euphotic zone. The upper region represented the persistently low-nutrient, high-light conditions within the mixed layer where rates of ${ }^{14} \mathrm{C}$-bicarbonate assimilation have been shown to be light-saturated (Church et al. 2004, Li et al. 2011, Viviani et al. 2015). In contrast, the lower euphotic zone represented the nutrientenriched, but low-light portion of the upper pycnocline where rates of plankton production are lightlimited (Letelier et al. 2004, Li et al. 2011).

\section{RESULTS}

\section{Variability in upper ocean biogeochemistry}

Biogeochemical conditions in the upper ocean during our study period (May 2012 to May 2013) were consistent with the long-term HOT program climatology at Station ALOHA (Fig. 1). The depth of the mixed layer ranged from $\sim 36$ to $60 \mathrm{~m}$ from the late spring through fall, deepening to $\sim 77$ to $126 \mathrm{~m}$ between December to April (Table 1). The flux of PAR at $25 \mathrm{~m}$ (within the upper euphotic zone) was greatest from April to August, with lowest fluxes ( 3-fold lower) in December (Table 1, Fig. 1A). Downwelling PAR flux at $100 \mathrm{~m}$ (within the lower euphotic zone) tended to be greatest between April and June and declined steadily thereafter (Fig. 1B). The depth of the $1 \%$ surface PAR isopleth was relatively stable during our study period, shoaling to $106-110 \mathrm{~m}$ between August and February and deepening to 115-118 m between March and June (Table 1). Inventories of $\mathrm{NO}_{3}{ }^{-}+\mathrm{NO}_{2}{ }^{-}$in the well-lit regions of the upper euphotic zone were persistently low and demonstrated no apparent seasonality (1-way ANOVA, $p=0.97$, Fig. 1C). In contrast, $\mathrm{NO}_{3}{ }^{-}+\mathrm{NO}_{2}{ }^{-}$inventories in the lower euphotic zone were more temporally variable, with elevated concentrations in November, December, and February (pairwise Tukey and Kramer, $\mathrm{p}<0.05$, Fig. 1D). Inventories of HOT program chl $a$ in the upper euphotic zone were temporally variable (KruskalWallis, $\mathrm{p}<0.0001$ ), with generally elevated concentrations from November to February compared to the other months (pairwise Tukey and Kramer, $\mathrm{p}<0.05$, Fig. 1E). Chl $a$ inventories in the lower euphotic zone were not significantly different on monthly time scales (ANOVA, $p=0.18$, Fig. 1F). 

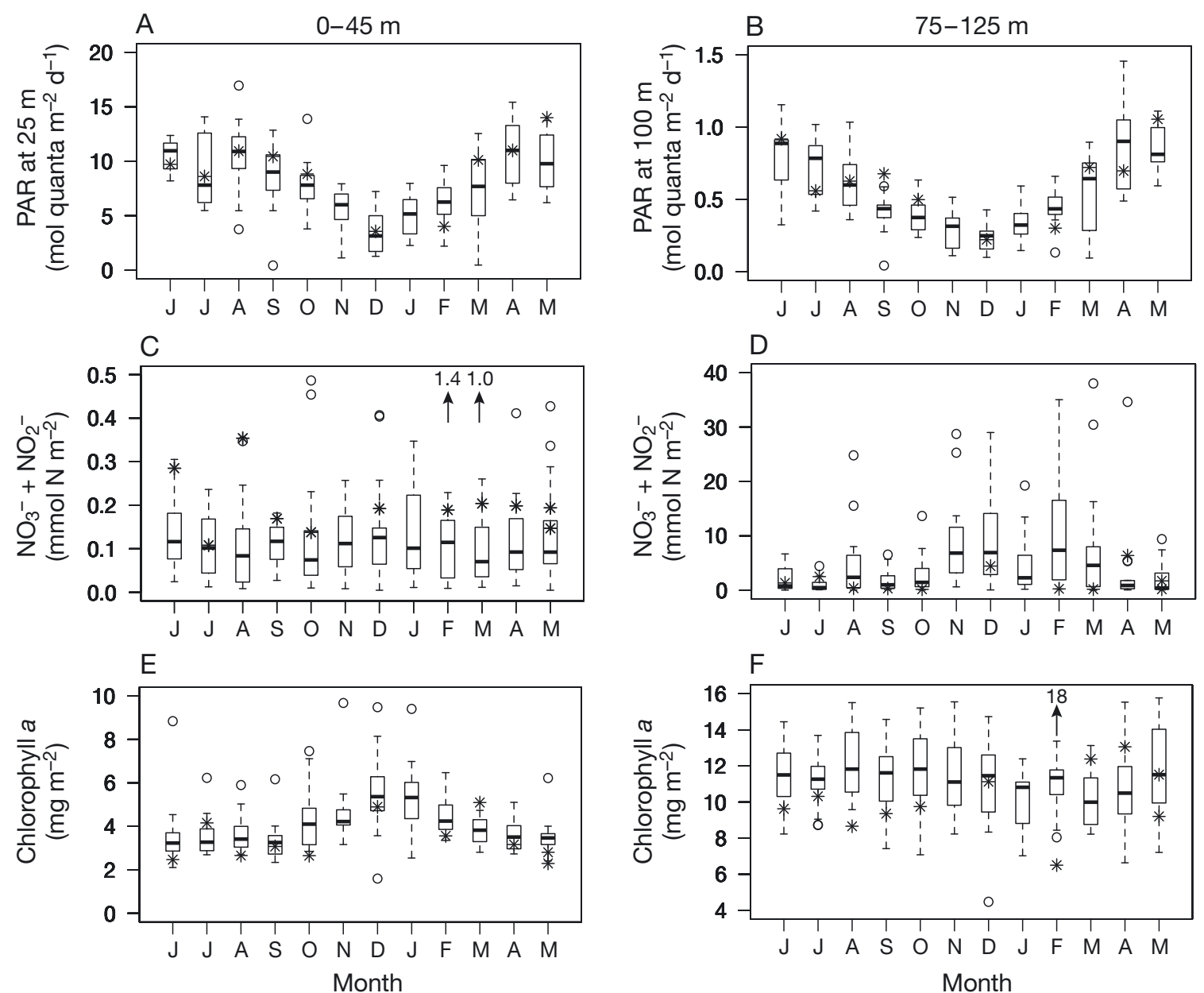

Fig. 1. Monthly-binned biogeochemical properties at Station ALOHA: daily PAR flux (1998-2013) at (A) $25 \mathrm{~m}$ and (B) $100 \mathrm{~m}$; $\mathrm{NO}_{3}{ }^{-}+\mathrm{NO}_{2}^{-}(1989-2013)$ in the (C) upper (0-45 m) and (D) lower (75-125 m) euphotic zone; and inventories of chl $a$ (1989-2013) in the (E) upper and (F) lower euphotic zone. Note scale differences between the panels. Measurements conducted as part of the current study (May 2012 to May 2013) are symbolized as stars (*). For each boxplot: dark horizontal line indicates the median, the box boundaries span the 1st (25th percentile) to the 3rd quartile (75th percentile), and the whiskers extend to the maximum and minimum (boundary $\pm 1.5 \times$ interquartile range) of the selected measurements. Outlier observations, considered to be beyond the maximum and minimum limits of the observations, are depicted as open circles, and observations falling outside the scale of the plot region are indicated by arrows and measurement values

\section{Size partitioning of ${ }^{14} \mathrm{C}$ primary productivity}

In general, picophytoplankton contributions to depth-integrated $(0-125 \mathrm{~m})$ rates of ${ }^{14} \mathrm{C}$ assimilation were $\sim 3$-fold greater (ranging from 8.8 to $26.4 \mathrm{mmol}$ $\mathrm{C} \mathrm{m}^{-2} \mathrm{~d}^{-1}$ ) than contributions by phytoplankton $>3 \mu \mathrm{m}$ (ranging from 2.5 to $8.8 \mathrm{mmol} \mathrm{C} \mathrm{m}^{-2} \mathrm{~d}^{-1}$; Table 2). Picophytoplankton comprised $\sim 68$ to $83 \%$ of total depth-integrated $(0-125 \mathrm{~m})$ rates of productivity, with their contributions to total ${ }^{14} \mathrm{C}$ primary productivity somewhat greater in the lower (76-90\%) than in the upper (65-78\%) euphotic zone (Welch's $t$-test, $\mathrm{p}<0.005$; Table 2). Approximately half (41-59\%) of the 0-125 m picophytoplankton ${ }^{14} \mathrm{C}$-based productivity occurred in the upper euphotic zone, while greater than half $(55-75 \%)$ of the $0-125 \mathrm{~m}>3 \mu \mathrm{m}$ production occurred in the upper euphotic zone (Fig. 2). In the upper euphotic zone, rates of ${ }^{14} \mathrm{C}$ based picophytoplankton productivity were greatest between May and July 2012, and between March and May 2013 (Table 2); in the lower euphotic zone, depth-integrated rates of picophytoplankton primary production were lowest in December $2012(\sim 1.5 \mathrm{mmol}$ C $\mathrm{m}^{-2} \mathrm{~d}^{-1}$ ) and increased $\sim 5$-fold in March 2013 (Table 2).

\section{Variability in picophytoplankton cell abundances and biomass}

Picophytoplankton cell abundances measured during our study were consistent with the historical HOT 
Table 2. Depth-integrated rates of size-fractionated ${ }^{14} \mathrm{C}$ primary production in the upper, lower, and total euphotic zone. Shown are mean \pm SD of triplicate bottles (in mmol $\mathrm{C} \mathrm{m}^{-2} \mathrm{~d}^{-1}$ ); values in parentheses are percentages \pm SD of each size fraction relative to the total ( $>0.2 \mu \mathrm{m}$ ) ${ }^{14} \mathrm{C}$ primary production. Cruises as in Table 1, except for $\mathrm{H} 243$ for which samples were compromised

\begin{tabular}{|llccccccc}
\hline Cruise & Date & \multicolumn{2}{c|}{ Upper $(0-45 \mathrm{~m})$} & \multicolumn{2}{c}{ Lower $(75-125 \mathrm{~m})$} & Total $(0-125 \mathrm{~m})$ \\
& & $0.2-3 \mu \mathrm{m}$ & $>3 \mu \mathrm{m}$ & $0.2-3 \mu \mathrm{m}$ & $>3 \mu \mathrm{m}$ & $0.2-3 \mu \mathrm{m}$ \\
\hline H242 & 30 May 2012 & $9.3 \pm 1.9(67 \pm 17)$ & $4.7 \pm 0.6(33 \pm 7)$ & $4.1 \pm 0.4(78 \pm 10)$ & $1.1 \pm 0.1(22 \pm 2)$ & $18.6 \pm 2.0(70 \pm 9)$ & $7.9 \pm 0.8(30 \pm 4)$ \\
HD5 & 12 Jul 2012 & $15.3 \pm 1.5(74 \pm 10)$ & $5.3 \pm 0.8(26 \pm 5)$ & $4.0 \pm 0.3(79 \pm 7)$ & $1.1 \pm 0.1(21 \pm 2)$ & $26.4 \pm 1.7(75 \pm 7)$ & $8.8 \pm 1.0(25 \pm 3)$ \\
H245 & 17 Aug 2012 & $6.1 \pm 0.7(66 \pm 9)$ & $3.1 \pm 0.2(34 \pm 3)$ & $4.0 \pm 0.4(88 \pm 13)$ & $0.5 \pm 0.0(12 \pm 1)$ & $13.6 \pm 1.3(74 \pm 9)$ & $4.9 \pm 0.2(26 \pm 2)$ \\
H246 & 14 Sep 2012 & $4.3 \pm 0.3(71 \pm 8)$ & $1.7 \pm 0.2(29 \pm 3)$ & $3.1 \pm 0.1(86 \pm 4)$ & $0.5 \pm 0.0(14 \pm 1)$ & $10.1 \pm 0.4(76 \pm 4)$ & $3.1 \pm 0.2(24 \pm 2)$ \\
H247 & 07 Oct 2012 & $3.9 \pm 0.7(66 \pm 15)$ & $2.0 \pm 0.2(34 \pm 5)$ & $2.6 \pm 0.3(84 \pm 13)$ & $0.5 \pm 0.0(16 \pm 2)$ & $8.8 \pm 0.9(71 \pm 9)$ & $3.6 \pm 0.3(29 \pm 3)$ \\
H248 & 03 Dec 2012 & $5.3 \pm 0.6(74 \pm 11)$ & $1.9 \pm 0.1(26 \pm 3)$ & $1.5 \pm 0.3(89 \pm 25)$ & $0.2 \pm 0.0(11 \pm 2)$ & $9.0 \pm 0.8(78 \pm 8)$ & $2.5 \pm 0.2(22 \pm 2)$ \\
H249 & 12 Feb 2013 & $6.2 \pm 1.2(65 \pm 16)$ & $3.3 \pm 0.2(35 \pm 5)$ & $2.4 \pm 0.4(84 \pm 19)$ & $0.5 \pm 0.0(16 \pm 3)$ & $11.9 \pm 1.3(71 \pm 10)$ & $4.9 \pm 0.2(29 \pm 3)$ \\
H250 & 06 Mar 2013 & $10.5 \pm 0.2(78 \pm 2)$ & $3.0 \pm 0.1(22 \pm 1)$ & $6.7 \pm 0.8(90 \pm 14)$ & $0.8 \pm 0.1(10 \pm 2)$ & $25.4 \pm 1.0(83 \pm 4)$ & $5.1 \pm 0.2(17 \pm 1)$ \\
H251 & 05 Apr 2013 & $9.1 \pm 0.7(76 \pm 8)$ & $2.8 \pm 0.3(24 \pm 3)$ & $4.7 \pm 0.4(85 \pm 8)$ & $0.8 \pm 0.0(15 \pm 1)$ & $19.2 \pm 1.1(79 \pm 6)$ & $5.1 \pm 0.3(21 \pm 2)$ \\
H252 & 17 May 2013 & $9.4 \pm 0.8(67 \pm 7)$ & $4.5 \pm 0.5(33 \pm 4)$ & $2.7 \pm 0.4(76 \pm 15)$ & $0.9 \pm 0.1(24 \pm 3)$ & $16.1 \pm 0.9(68 \pm 5)$ & $7.7 \pm 0.5(32 \pm 3)$ \\
\hline
\end{tabular}

program measurements of these organisms. Cell abundances ranged from $36.8 \times 10^{9}$ to $336.3 \times 10^{9}$ cells $\mathrm{m}^{-3}$, below detection to $5.4 \times 10^{9}$ cells m$^{-3}$, and $0.5 \times 10^{9}$ to $2.3 \times 10^{9}$ cells m$^{-3}$ for Prochlorococcus, Synechococcus, and PPE, respectively (Fig. 3A-C). Prochlorococcus cell abundances in the upper $125 \mathrm{~m}$ were relatively stable during our sampling period, demonstrating $~ 1.5$-fold increases in April and May 2013 (Table 1). Similarly, PPE cell abundances were also relatively stable, varying $\sim 2$-fold over the sampling period, with lowest abundances in October 2012 (Table 1). In contrast, Synechococcus cell abundances were more dynamic, varying $\sim 3$ - to 5-fold, with largest increases in abundance observed between February and April 2013.

Picophytoplankton mean cell diameters were estimated from flow cytometric measurements of FSC using an empirical equation derived using cultures of Prochlorococcus and several PPE (Table A1). For this study, estimated picophytoplankton cell sizes in the $0-125 \mathrm{~m}$ were $0.4 \pm 0.3,0.7 \pm 0.4$, and $1.5 \pm 1.1 \mu \mathrm{m}$ for Prochlorococcus, Synechococcus, and PPE, respectively (Table A2). The resulting average per cell carbon content ranged from 9 to $12 \mathrm{fg} \mathrm{C} \mathrm{cell}^{-1}$ for Prochlorococcus, 43 to $50 \mathrm{fg} \mathrm{C}^{\mathrm{C}} \mathrm{cell}^{-1}$ for Synechococcus, and 445 to $453 \mathrm{fg} \mathrm{C}^{\mathrm{C}} \mathrm{cell}^{-1}$ for PPE (Table A2). While both Prochlorococcus and Synechococcus mean cell diameters increased $\sim 20 \%$ from the upper to the lower regions of the euphotic zone, PPE mean cell diameters decreased $\sim 8 \%$ (Table A2).

Estimations of carbon biomass derived from measured cell abundances and biovolumes revealed that Prochlorococcus, Synechococcus, and PPE comprised $61-78,2-8$, and $21-36 \%$, respectively, of the summed picophytoplankton biomass in the euphotic zone $(0-125 \mathrm{~m}$; Table 3$)$. The biomass of Prochlorococcus and PPE in the euphotic zone were relatively stable in time, varying $\sim 2$-fold over the study period (ranging from 9.1 to $20.9 \mathrm{mmol} \mathrm{C} \mathrm{m}^{-2}$ and 3.1 to 7.7 mmol $\mathrm{C} \mathrm{m}^{-2}$, respectively) with highest biomass observed during the summer and spring months (Table 3). In contrast, Synechococcus biomass varied 13-fold (ranging from 0.2 to $2.6 \mathrm{mmol} \mathrm{C} \mathrm{m}^{-2}$ ), with biomass greatest in February, March, and April of 2013 (Table 3).

Temporal variability of Prochlorococcus, Synechococcus, and PPE revealed differing dynamics in the upper and the lower regions of the euphotic zone. Depth-integrated biomass of each picophytoplankton group in the upper euphotic zone was similar to its biomass in the lower euphotic zone; however, variability in Prochlorococcus biomass in the lower euphotic zone was greater than in the upper euphotic zone, while PPE biomass exhibited greater variability in the upper compared to the lower euphotic zone (Fig. 3D,F). In the upper euphotic zone, seasonal increases during the spring and summer months were apparent in biomass of Prochlorococcus and PPE, with the largest increases in biomass observed from fall months to spring ( 4 -fold increase from September 2012 to March 2013 for Prochlorococcus and 4-fold increase from September 2012 to May 2013 for PPE; Fig. 4A). Synechococcus biomass was also elevated in spring, demonstrating a 16-fold increase from September 2012 to March 2013 in the upper euphotic zone (Fig. 4A). In the lower euphotic zone, PPE biomass varied $\sim 2$-fold, with peak inventories in the spring and summer months (Fig. 4B). Similarly, Synechococcus biomass increased 8-fold in March 2013 compared to other months. Prochlorococcus biomass fluctuated throughout the year, with 2-fold higher inventories in June, August, and December 2012 and March 2013 compared to other months (Fig. 4B). 

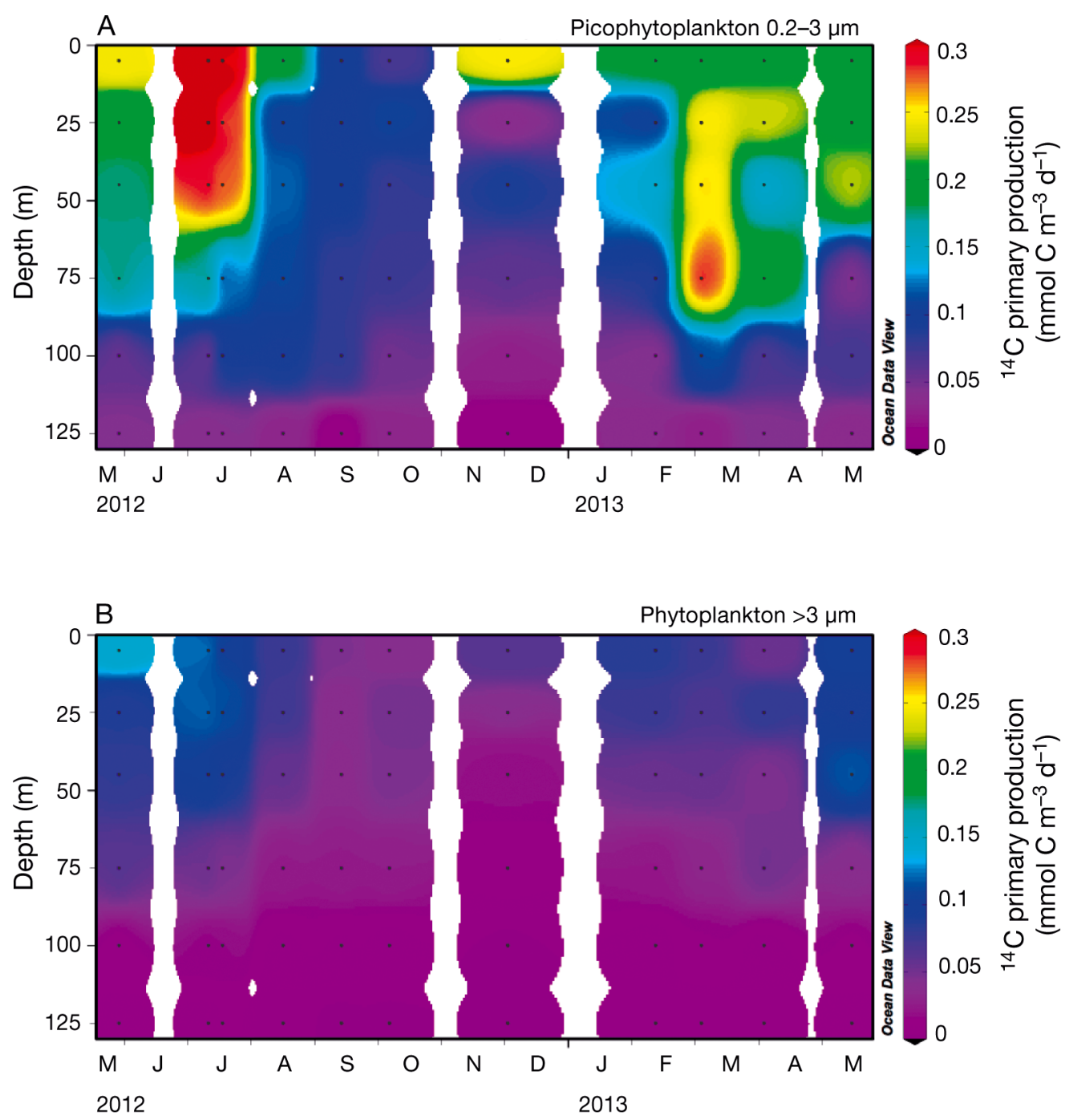

Fig. 2. Rates of ${ }^{14} \mathrm{C}$-primary production by (A) pico- $(0.2-3 \mu \mathrm{m})$ and (B) larger ( $\left.>3 \mu \mathrm{m}\right)$ phytoplankton between May 2012 and May 2013. Black circles indicate sampling depths, and values are means of triplicate samples

\section{Group- and cell-specific rates of ${ }^{14} \mathrm{C}$ assimilation, and biomass-normalized production}

Prochlorococcus, Synechococcus, and PPE comprised $39 \pm 20,1.6 \pm 1.7$, and $11 \pm 6 \%$ of the total $(>0.2 \mu \mathrm{m}){ }^{14} \mathrm{C}$ primary productivity, respectively. Prochlorococcus accounted for 63 to $86 \%$ of the $0-125 \mathrm{~m}$ depth-integrated rates of sorted picophytoplankton ${ }^{14} \mathrm{C}$-production, with Synechococcus and PPE accounting for the remaining 1 to $8 \%$ and 12 to $36 \%$, respectively (Table 3). Relative contributions by Prochlorococcus to picophytoplankton production demonstrated modest increases with depth, accounting for $81 \pm 5 \%$ of the summed picophytoplankton productivity in the lower euphotic zone compared to $72 \pm$ $9 \%$ in the upper euphotic zone (Welch's $t$-test, $\mathrm{p}<$ 0.05 ; Fig. 5). In contrast, relative contributions by PPE tended to be greater in the upper euphotic zone relative to the lower euphotic zone $(25 \pm 9 \%$ versus $17 \pm$ $6 \%$; Welch's $t$-test, $\mathrm{p}<0.05$; Fig. 5). Group-specific rates of ${ }^{14} \mathrm{C}$-productivity by Prochlorococcus varied $\sim 5$-fold during our study period, with elevated rates between June and August 2012 and between March and May 2013, and lowest rates in October 2012 (Table 3, Fig. 5). Group-specific rates of production by Synechococcus varied as much as $\sim 30$-fold during this study, with the highest rates in June to August 2012 and March to May 2013, and lowest in September 2012. These large increases in group-specific rates of production by Prochlorococcus and Synechococcus in summer 2012 and spring 2013 also coincided with periods of elevated production in the picophytoplankton filter fraction (Fig. 2). For PPE, group-specific rates of ${ }^{14} \mathrm{C}$-productivity varied 

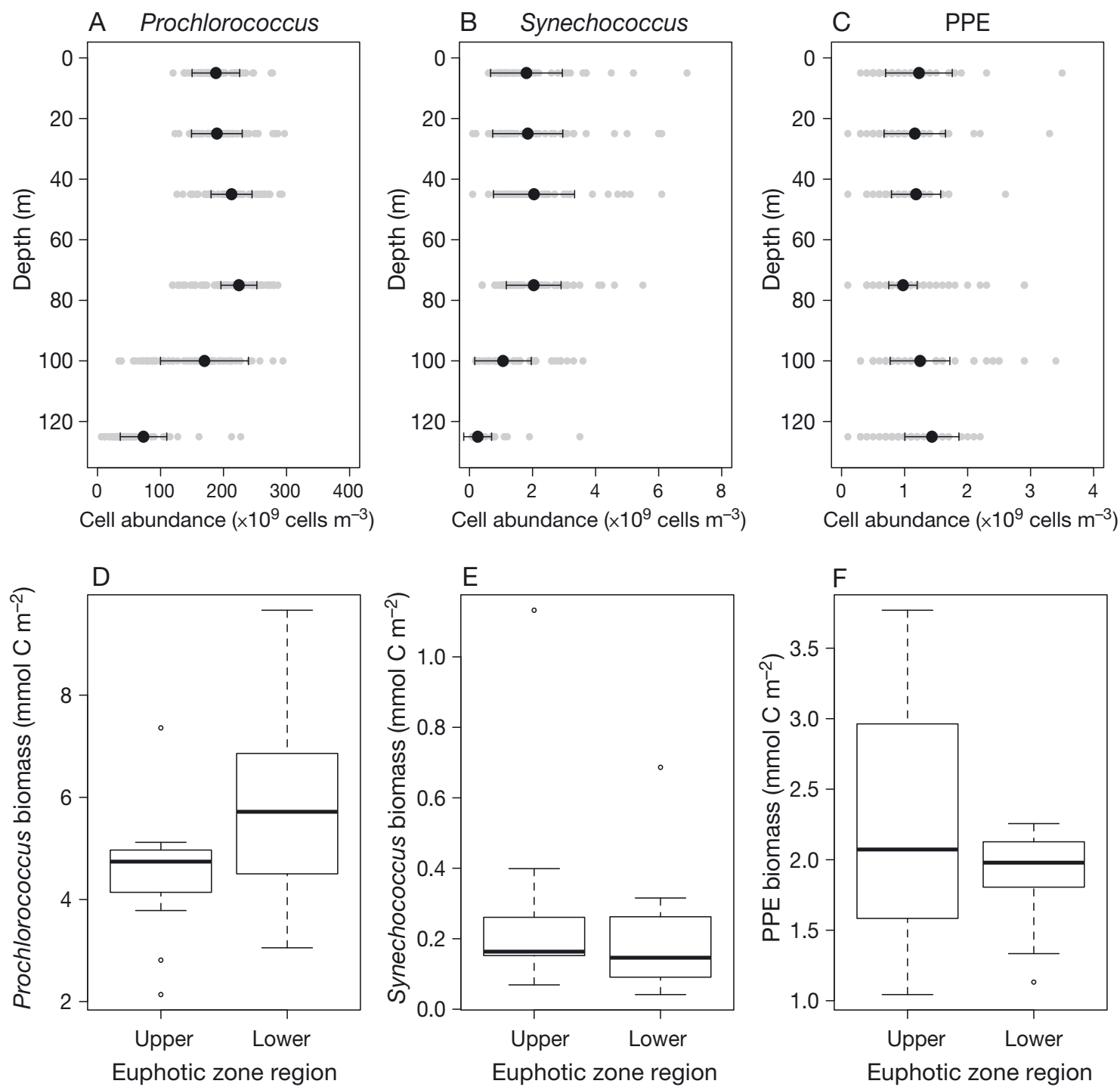

Fig. 3. (A) Prochlorococcus, (B) Synechococcus, and (C) photosynthetic picoeukaryotes (PPE) cell abundances at Station ALOHA between 2006 and 2013 (grey circles), with overlay of black circles (mean) and error bars (standard deviations) for measurements obtained during the current study period (May 2012 to May 2013). Note scale differences between the panels. Depth-integrated estimated carbon biomass of (D) Prochlorococcus, (E) Synechococcus, and (F) PPE in the upper (0-45 m) and lower $(75-125 \mathrm{~m}$ ) euphotic zone (from this study) are shown, with the same boxplot boundaries as those described in Fig. 1

$\sim 4$-fold in time, with lowest rates in December 2012 and elevated rates in June to July 2012 and February to May 2013 (Table 3). Combined, the sum of sorted picophytoplankton productivity accounted for $52 \%$ (on average) of the total ${ }^{14} \mathrm{C}$ primary productivity (sum of the filter size fractions) and $70 \pm 32 \%$ of the picophytoplankton filter-based $(0.2-3 \mu \mathrm{m})$ primary productivity.

Normalizing the sort-based rates of productivity to cell abundances highlighted large differences in cellspecific production by these groups of picophytoplankton. Cell-specific rates of ${ }^{14} \mathrm{C}$-production by Prochlorococcus were generally low (averaging $0.4 \pm$
$0.2 \mathrm{fmol} \mathrm{C} \mathrm{cell}^{-1} \mathrm{~d}^{-1}$ ), with Synechococcus exhibiting somewhat higher rates (averaging $1.6 \pm 1.2 \mathrm{fmol} \mathrm{C}$ cell $^{-1} \mathrm{~d}^{-1}$ ). In contrast, PPE demonstrated rates (averaging $16 \pm 12 \mathrm{fmol} \mathrm{C}$ cell ${ }^{-1} \mathrm{~d}^{-1}$ ) that were 25 - to 95-fold greater than those by Prochlorococcus (Fig. 6). Throughout this study period, depth-integrated $(0-125 \mathrm{~m})$ Prochlorococcus and Synechococcus cell-specific rates of ${ }^{14} \mathrm{C}$-assimilation appeared temporally dynamic, with rates lowest between August and October 2012 and increasing between February and March 2013, with the highest rates measured in March 2013 (Fig. 6A,C). Cell-specific rates of production by PPE tended to be less variable, 
Table 3. Depth-integrated (0-125 m) rates of picophytoplankton (PRO: Prochlorococcus, SYN: Synechococcus, PPE: photosynthetic picoeukaryotes) biomass, group-specific carbon fixation, and biomass-normalized production. Biomass was calculated

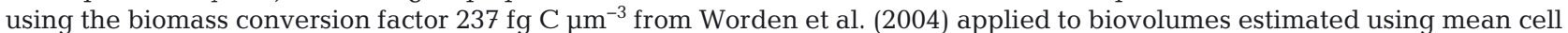
diameters and assuming a spherical shape. Values in parentheses are the percentage contribution of each group relative to the summed contributions of PRO, SYN, and PPE. Cruises as in Table 1

\begin{tabular}{|c|c|c|c|c|c|c|c|c|c|c|}
\hline \multirow[t]{2}{*}{ Cruise } & \multirow[t]{2}{*}{ Date } & \multicolumn{3}{|c|}{$\begin{array}{c}\text { Biomass } \\
\left(\mathrm{mmol} \mathrm{C} \mathrm{m}{ }^{-2}\right)\end{array}$} & \multicolumn{3}{|c|}{ 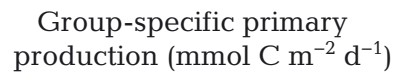 } & \multicolumn{3}{|c|}{$\begin{array}{l}\text { Biomass-normalized } \\
\text { production }\left(\mathrm{d}^{-1}\right)\end{array}$} \\
\hline & & PRO & SYN & PPE & PRO & SYN & PPE & PRO & SYN & PPE \\
\hline H242 & 30 May 2012 & $10.4(63)$ & $0.4(2)$ & $5.6(34)$ & $4.7(73)$ & $0.1(2)$ & $1.7(25)$ & 0.45 & 0.29 & 0.29 \\
\hline H243 & 25 Jun 2012 & $15.5(72)$ & $0.5(2)$ & $5.6(26)$ & $10.4(77)$ & $0.3(2)$ & $2.8(21)$ & 0.67 & 0.57 & 0.49 \\
\hline HD5 & 12 Jul 2012 & $11.2(69)$ & $0.4(2)$ & $4.6(29)$ & 9.7 (79) & $0.3(2)$ & 2.3 (19) & 0.86 & 0.82 & 0.50 \\
\hline H245 & 17 Aug 2012 & $17.3(74)$ & $0.4(2)$ & $5.6(24)$ & $9.5(81)$ & $0.3(3)$ & $1.9(16)$ & 0.54 & 0.67 & 0.34 \\
\hline H246 & 14 Sep 2012 & $10.2(71)$ & $0.2(2)$ & $3.9(27)$ & $5.0(75)$ & $0.1(1)$ & $1.6(24)$ & 0.49 & 0.26 & 0.42 \\
\hline $\mathrm{H} 247$ & 07 Oct 2012 & $9.1(73)$ & $0.3(2)$ & $3.1(25)$ & $3.1(74)$ & $0.1(3)$ & $1.0(23)$ & 0.34 & 0.51 & 0.31 \\
\hline H248 & 03 Dec 2012 & $14.6(78)$ & $0.3(2)$ & $3.8(21)$ & $5.8(86)$ & $0.1(2)$ & $0.8(12)$ & 0.40 & 0.45 & 0.20 \\
\hline H249 & 12 Feb 2013 & $12.3(61)$ & $0.9(5)$ & $7.0(34)$ & 7.3 (69) & $0.4(4)$ & $2.9(27)$ & 0.60 & 0.44 & 0.41 \\
\hline $\mathrm{H} 250$ & 06 Mar 2013 & 20.9 (68) & $2.6(8)$ & $7.3(24)$ & $16.5(76)$ & $1.7(8)$ & 3.5 (16) & 0.79 & 0.67 & 0.47 \\
\hline $\mathrm{H} 251$ & 05 Apr 2013 & $13.3(69)$ & $0.9(5)$ & $5.0(26)$ & $11.4(80)$ & $0.5(3)$ & $2.5(17)$ & 0.85 & 0.50 & 0.49 \\
\hline $\mathrm{H} 252$ & 17 May 2013 & $13.5(62)$ & $0.4(2)$ & $7.7(36)$ & 8.1 (63) & $0.2(1)$ & $4.6(36)$ & 0.60 & 0.44 & 0.61 \\
\hline
\end{tabular}
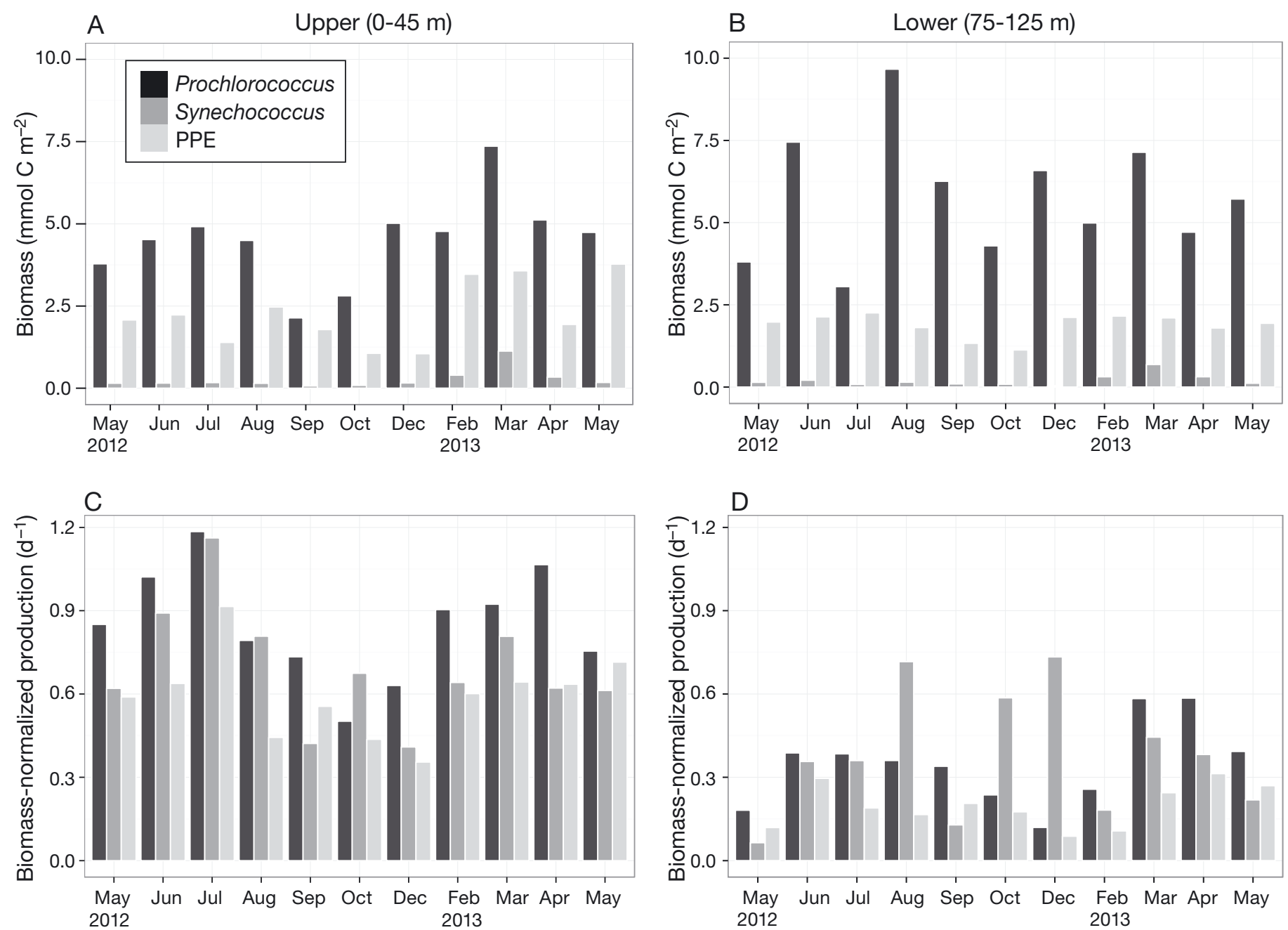

Fig. 4. Temporal variability in (A, B) derived biomass and (C, D) biomass-normalized production by Prochlorococcus (dark grey bars), Synechococcus (medium grey bars), and photosynthetic picoeukaryotes (PPE, light grey bars) between May 2012 and May 2013 
May 2012

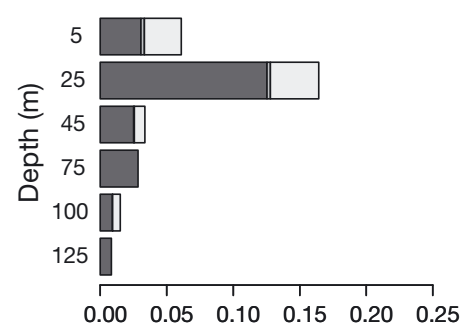

Sep 2012

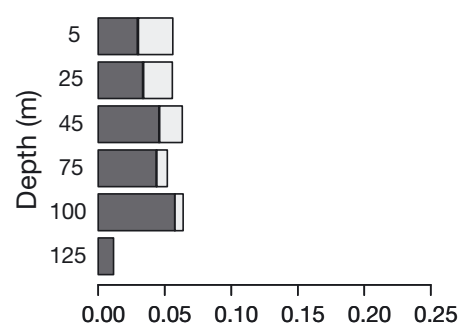

Mar 2013

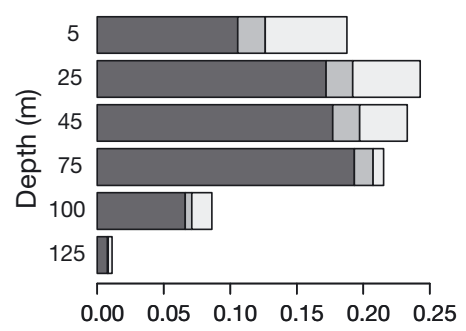

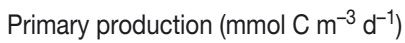

Jun 2012

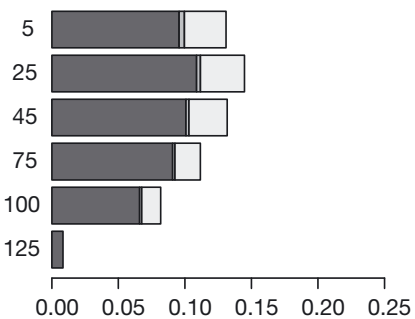

Oct 2012

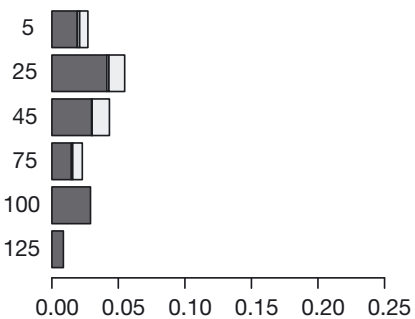

Apr 2013

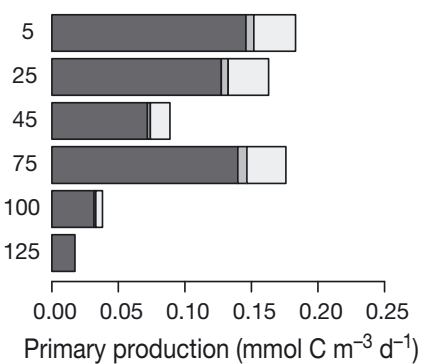

Jul 2012

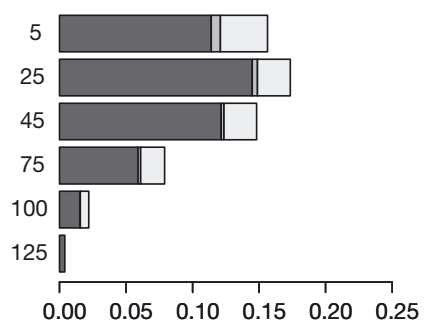

Dec 2012

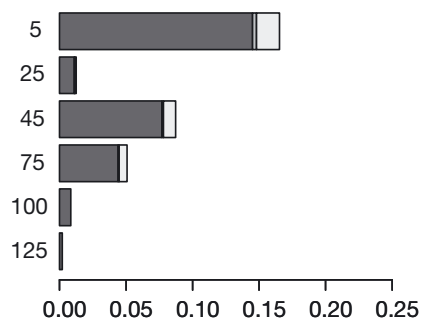

May 2013

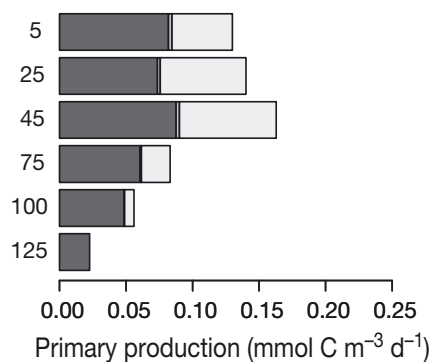

Aug 2012

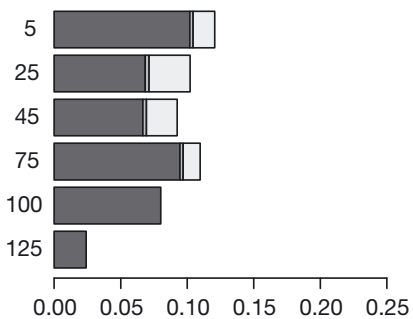

Feb 2013

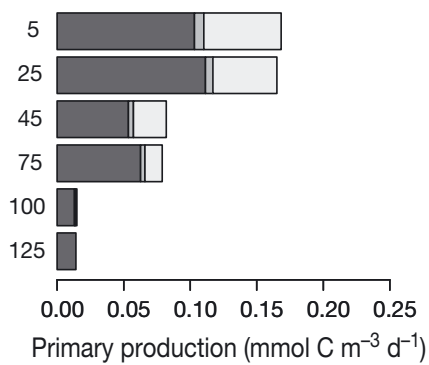

Prochlorococcus Synechococcus PPE

Fig. 5. Vertical profiles of group-specific rates of ${ }^{14} \mathrm{C}$-based primary productivity by Prochlorococcus (dark grey bars), Synechococcus (medium grey bars), and photosynthetic picoeukaryotes (PPE, light grey bars) between May 2012 and May 2013. Due to insufficient number of cells sorted, Synechococcus contributions were not measured at $100 \mathrm{~m}$ in August, October, and December 2012, and not measured at $125 \mathrm{~m}$ in all months sampled except March 2013

with the greatest changes in cell-specific productivity occurring in the upper euphotic zone and with the highest rates observed in May 2013 (Fig. 6E). PPE cell-specific rates were significantly greater $(3.5$-fold on average) in the well-lit waters $(<45 \mathrm{~m})$ than in the lower euphotic zone (Kruskal-Wallis, $\mathrm{p}<0.005$, Fig. 6F). In comparison, cell-specific rates of ${ }^{14} \mathrm{C}$ primary productivity for both Prochlorococcus and Synechococcus in the upper euphotic zone were $\sim 1.7$-fold greater than rates in the lower euphotic zone (Kruskal-Wallis, $\mathrm{p}<0.005$, Fig. 6B, D).

Estimates of biomass-normalized production in the euphotic zone (0-125 m) for Prochlorococcus, Synechococcus, and PPE ranged from 0.3 to $0.9,0.3$ to 0.8 , and 0.2 to $0.6 \mathrm{~d}^{-1}$, respectively (Table 3 ). Normalized rates of production by Prochlorococcus and Syne- chococcus were typically greater than PPE, with Prochlorococcus and Synechococcus in the upper euphotic zone averaging $0.9 \pm 0.2$ and $0.7 \pm 0.2 \mathrm{~d}^{-1}$, respectively, while PPE averaged $0.6 \pm 0.2 \mathrm{~d}^{-1}$ (Fig. 4C). In the lower euphotic zone, normalized rates of production were lower, averaging $0.3 \pm 0.1$, $0.4 \pm 0.2$, and $0.2 \pm 0.1 \mathrm{~d}^{-1}$ for Prochlorococcus, Synechococcus, and PPE, respectively (Fig. 4D). For all picophytoplankton, the highest biomass-normalized rates of production in the upper euphotic zone occurred in July 2012, where rates were $~ 3$-fold greater than in October to December 2012 (Fig. 4C). In the lower euphotic zone, rates by Prochlorococcus and PPE varied 5- and 4-fold, respectively, over the course of the study, with rates greatest in March and April 2013 (Fig. 4D). 

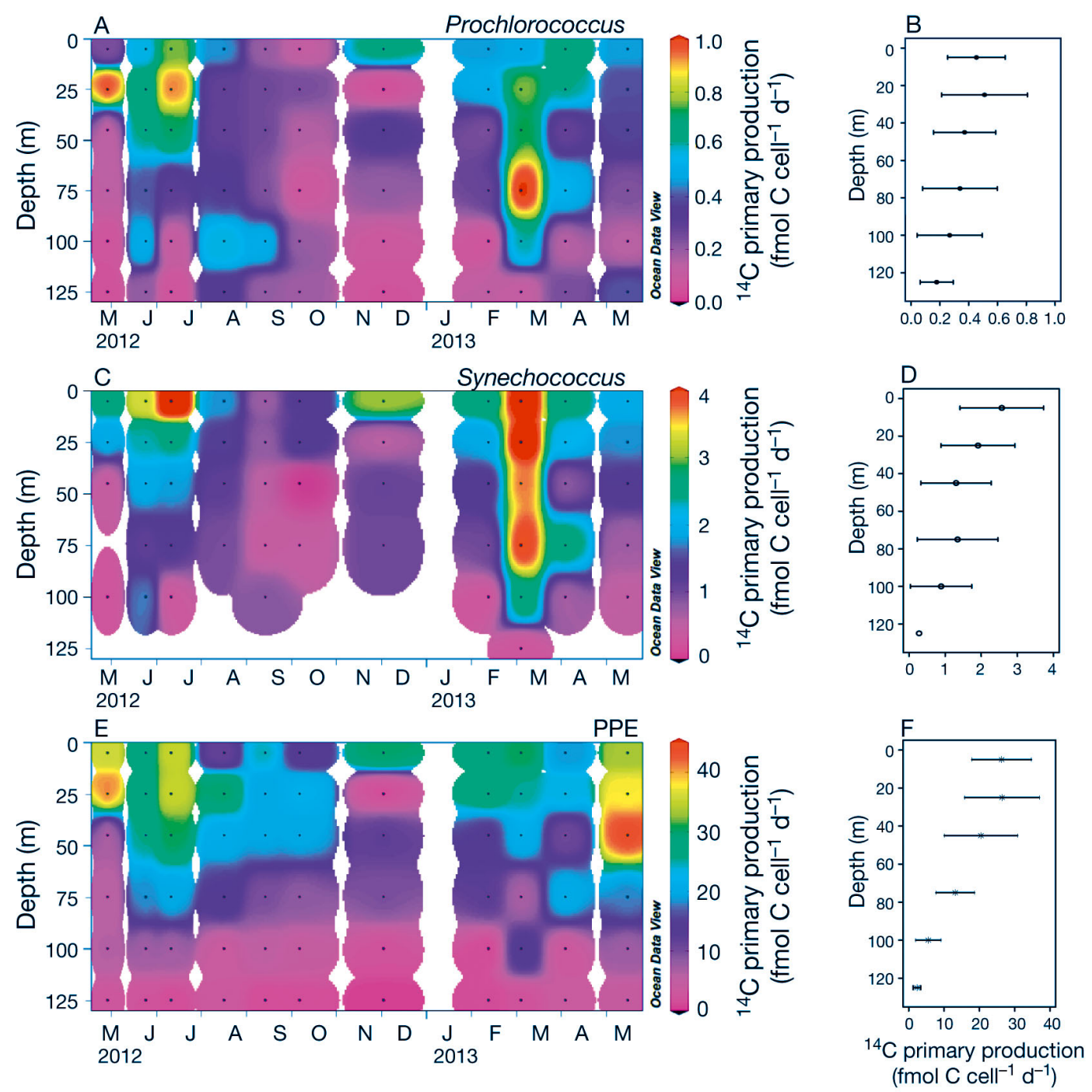

Fig. 6. Cell-specific rates of ${ }^{14} \mathrm{C}$ primary productivity by (A, B) Prochlorococcus, $(\mathrm{C}, \mathrm{D})$ Synechococcus, and (E, F) photosynthetic picoeukaryotes (PPE) between May 2012 and May 2013. Black circles in A, C, and E indicate sampling depths. Symbols and error bars depicted in B, D, and F are time-averaged means and SD. Note scale differences between the panels

\section{DISCUSSION}

We examined the vertical and temporal variability in rates of picophytoplankton ${ }^{14} \mathrm{C}$-based primary productivity at Station ALOHA in the oligotrophic NPSG based on filter size fractionation and flow cytometric sorting of radiolabeled cell populations. Picophytoplankton dominated rates of ${ }^{14} \mathrm{C}$-based primary production, accounting for $>70 \%$ of the total productivity throughout the year. This finding is consistent with past studies that have observed the importance of picophytoplankton to carbon cycling in both oligotrophic and nutrient-rich waters (e.g. Li 1994, Agawin et al. 2000, Marañón et al. 2001, Li et al. 2011, Buitenhuis et al. 2012, Rii et al. 2016). In the current study, greatest rates of both filter-based and sorted ${ }^{14} \mathrm{C}$ - based primary productivity were measured in the spring and summer months in the upper euphotic zone, while peak productivity in the lower euphotic zone corresponded with periods when the flux of light to the lower euphotic zone was greatest (March to April 2013). Moreover, the observed depth variability in the size partitioning of productivity indicated that while picophytoplankton contributed to primary production throughout the euphotic zone, larger ( $>3 \mu \mathrm{m})$ phytoplankton contributions were greater in the upper euphotic zone compared to in deeper waters. These findings suggest that in this ecosystem, picophytoplankton may be better adapted to low-light regions of the euphotic zone than larger phytoplankton.

Consistent with the numerical dominance and estimated carbon biomass of Prochlorococcus, these 
organisms contributed $>60 \%$ to the total sorted picophytoplankton productivity (equaling $\sim 39 \%$ of total $>0.2 \mu \mathrm{m}$ filter-based productivity), which agrees with previously reported measurements at Station ALOHA (Björkman et al. 2015). In contrast to ProchlorococCUS, PPE cell abundances were orders of magnitude lower; however, PPE contributed up to $36 \%$ to sorted picophytoplankton production and biomass (equivalent to $\sim 11 \%$ to total filter-based productivity). These findings agree with the disproportionately high contributions of PPE (compared to cell abundance) to picophytoplankton production in the Atlantic and South Pacific Oceans (Li 1994, Jardillier et al. 2010, Rii et al. 2016), a finding we attribute to their larger cell size. Moreover, group- and cell-specific rates of primary productivity by PPE were greater in the upper $45 \mathrm{~m}$, suggesting that PPE may be adapted to rapid growth in well-lit regions of the euphotic zone. Our findings are supported by previous studies demonstrating positive correlations between PPE growth and irradiance (Bec et al. 2005), as well as the various photophysiological strategies of PPE to optimize growth in high-light environments, including synthesis and accumulation of photoprotective carotenoids and rapid modification of intracellular chl a concentration (Dimier et al. 2009, Brunet et al. 2011). Such photophysiological adaptations may provide PPE with competitive advantages over some cyanobacteria or larger phytoplankton in the well-lit upper ocean (Ferris \& Christian 1991, Dimier et al. 2009).

Our measurements allowed us to examine temporal variability in group-specific picophytoplankton production and estimated biomass over a 1 yr period. We observed that while PPE rates of production varied $\sim 4$-fold throughout the year with highest rates in May 2013, biomass varied $\sim 2.5$-fold, indicating that while PPE may be responding to conditions favoring production, removal processes including grazing, cell lysis, or export are tightly coupled to production, keeping biomass relatively stable. Similar dynamics were observed for Prochlorococcus, whose rates of production varied $\sim 5$-fold (highest rates in July 2012 and March 2013), while biomass varied 1.5-fold, resulting in relatively stable rates of normalized production throughout the year. In contrast, Synechococcus appeared more temporally dynamic, with group-specific rates of ${ }^{14} \mathrm{C}$-primary production increasing $\sim 30$-fold, with highest rates in summer 2012 and spring 2013, while biomass of these picophytoplankton increased $\sim 13$-fold in spring 2013. The resulting rates of biomass-normalized production for these groups ranged from 0.3 to $0.9 \mathrm{~d}^{-1}$ for Prochlorococcus, 0.3 to $0.8 \mathrm{~d}^{-1}$ for Synechococcus, and 0.2 to
$0.6 \mathrm{~d}^{-1}$ for PPE. These rates are similar to previously published estimates on growth rates of these picoplankton. For example, laboratory studies with Prochlorococcus isolates indicated maximal growth rates of $\sim 0.6 \mathrm{~d}^{-1}$ (Liu et al. 1995, Moore et al. 1995, Claustre et al. 2002). In a study in the subtropical North Pacific, Ribalet et al. (2015) estimated Prochlorococcus growth rates ranging from 0.2 to $0.9 \mathrm{~d}^{-1}$ based on diel changes in cell size and abundances. Measurements from the California coast reported growth rates estimated from dilution experiments to be $\sim 0.7 \mathrm{~d}^{-1}$ for Synechococcus and $\sim 1 \mathrm{~d}^{-1}$ for PPE (Worden et al. 2004).

Our findings highlight the important trophodynamic role of picophytoplankton in the oligotrophic ocean, with cell loss processes tightly coupled to cell growth. Our rates of production normalized to biomass were generally greater in the upper euphotic zone, presumably reflecting greater light availability. However, picophytoplankton biomass was comparable between the 2 regions of the euphotic zone, suggesting more rapid turnover of biomass in the upper euphotic zone. Such results are consistent with a number of studies quantifying cell loss processes in warm, well-lit regions of oligotrophic oceans that have found tight coupling between picoplankton growth and removal (Cochlan et al. 1993, Agusti et al. 1998, Liu et al. 1995, Worden et al. 2004). Moreover, our findings suggest that the degree of coupling between growth and removal differs amongst the picophytoplankton, with Prochlorococcus and PPE production apparently tightly coupled to removal processes, while the controls on Synechococcus production appear more variable. Thus, these results support the view that picophytoplankton growth can be critical to the transfer of organic material to higher trophic levels (Reckermann \& Veldhuis 1997, Brown et al. 1999, Worden et al. 2004).

Collectively, our measurements of production and estimated biomass suggest that various groups of picophytoplankton are growing rapidly in this ecosystem, despite persistently limited supply of nutrients to the upper ocean. While short-lived physical events can vertically transport nitrate at nearmonthly frequencies, such events appear largely restricted to the lower euphotic zone (Johnson et al. 2010). We suspect that the observed increase in net picophytoplankton growth in spring 2013 (largely due to Prochlorococcus and Synechococcus) may be a result of deepening isolumes during the spring, alleviating light-limited phytoplankton production in the lower euphotic zone and resulting in rapid consumption of nutrients (Letelier et al. 2004). Although 
many of the dominant ecotypes of Prochlorococcus appear incapable of growth on nitrate (Moore et al. 2002, Rocap et al. 2003), various studies have demonstrated the capacity for nitrate assimilation by selected ecotypes of Prochlorococcus (Casey et al. 2007, Martiny et al. 2009, Treibergs et al. 2014, Berube et al. 2015, 2016). In addition, the period of elevated Synechococcus production and biomass during the spring coincided with increased penetration of PAR and lower than average concentrations of nitrate in the lower euphotic zone, presumably reflecting seasonal drawdown of nutrients during production of new biomass. These results agree with past reports of Synechococcus responding significantly to seasonal elevations in light (DuRand et al. 2001) and nanomolar changes in nitrate concentration (Glover et al. 1988, 2007). Furthermore, our results suggest that while Synechococcus growth in the lower euphotic zone was responsive to variations in light and nutrients, changes in cell biomass were proportionally lower, indicating that rates of removal must vary vertically and temporally. Hence, despite their small size, picocyanobacteria may play a more significant role in transferring new nitrogen into the oceanic food web at Station ALOHA than previously estimated, thereby contributing to new production and export.

The works by Fawcett et al. $(2011,2014)$ and Painter et al. (2014), all conducted in the subtropical North Atlantic, provide evidence that PPE derive a significant fraction of their cellular nitrogen demand via assimilation of nitrate. However, it is not clear how applicable these results are to plankton nutritional dynamics at Station ALOHA in the subtropical North Pacific. There are significantly different dynamics with respect to nutrient supply in the North Atlantic compared to the North Pacific; for example, the highly seasonal convective mixing in the North Atlantic introduces a source of nitrate to the upper ocean, which supports a spring bloom-like productivity dynamic (Sieracki et al. 1993, Siegel et al. 2002). At Station ALOHA, the weak to moderate seasonal mixing dynamic results in an upper ocean persistently depleted in nitrate, and productivity peaks in the summer when the ocean is most stratified (Karl \& Church 2014). Moreover, while nitrate appears to be a major source of new nitrogen to the upper ocean in the subtropical North Atlantic, in the subtropical North Pacific, approximately half of the new nitrogen appears to derive from nitrogen fixation (Karl et al. 1997, Church et al. 2009, Böttjer et al. 2016). In our study, we found that PPE were most active in the upper $45 \mathrm{~m}$ of the euphotic zone, a region that, even with seasonal fluctuations of the mixed layer, rarely penetrates the nutricline. Therefore, even during winter mixing, the supply of nutrients to the upper euphotic zone remains very low, suggesting the PPE at Station ALOHA may be more reliant on recycled nutrient sources, facilitated in part by various forms of mixotrophic physiologies (Caron 2000, Zubkov \& Tarran 2008).

We calculated equivalent spherical diameters for Prochlorococcus, Synechococcus, and PPE based on flow cytometrically derived FSC. The resulting cell diameters $(0.4 \pm 0.3,0.7 \pm 0.4$, and $1.5 \pm 1.1 \mu \mathrm{m}$ for Prochlorococcus, Synechococcus, and PPE, respectively) tended to be lower than those reported in past studies (e.g. Bertilsson et al. 2003, Worden et al. 2004). Furthermore, use of a carbon conversion factor (237 fg $\mathrm{C} \mu \mathrm{m}^{-3}$, Worden et al. 2004) or application of an empirical function based on cell size (Eppley et al. 1970) yielded cellular carbon quotas somewhat lower than previously published estimates. For example, in a study in the Sargasso Sea, Casey et al. (2013) derived an empirical relationship between cellular carbon and FSC, yielding cellular carbon quotas for Prochlorococcus that ranged between 28 and $190 \mathrm{fg}$ C cell ${ }^{-1}$. Heldal et al. (2003) examined the elemental composition of single cells using X-ray microanalysis and estimated cell carbon quotas for Prochlorococcus between 17 and $34 \mathrm{fg} \mathrm{C}$ cell $^{-1}$, which were similar to those derived by Claustre et al. (2002) based on Prochlorococcus optical properties, and to carbon quotas of 15 to $65 \mathrm{fg} \mathrm{C}$ cell $^{-1}$ estimated by Shalapyonok et al. (2001). Based on these previous reports, we suspect our estimates of cell sizes may be biased low; however, given that we used the same approach throughout our time series, the resulting patterns provide insight into temporal dynamics in the coupling between productivity and accumulation of biomass.

One puzzling observation from the current study was the disagreement between the filter-based and the cell sort-based estimates of ${ }^{14} \mathrm{C}$ productivity. The sum of ${ }^{14} \mathrm{C}$ primary productivity in sorted cells accounted for $70 \pm 32 \%$ of the picophytoplankton filter size fraction, indicating that not all of the picophytoplankton ${ }^{14} \mathrm{C}$ primary productivity captured on filters was accounted for through cell sorting of the 3 picophytoplankton groups. These discrepancies between the filter-based and sorted picophytoplankton productivity may be due to a number of factors, including underrepresentation of less abundant, but active, phytoplankton. It is likely that the filter-based estimates of production included larger $(>3 \mu \mathrm{m})$ cells that were not quantitatively sampled by our flow 
sorting method. Temporal variability associated with the proportion of the sum of sorted productivity to the filter-based picophytoplankton productivity indicated that the proportions were greatest $(74-89 \%)$ between the winter and spring months (December to May). Such results suggest a greater abundance of larger organisms during summer and fall, which may have been caught on the filter but not in our sorts. These larger organisms may be associated with the annual summertime blooms of diatom-diazotroph assemblages that occur at Station ALOHA during periods of stratification (Dore et al. 2008). In addition, there may have been loss of ${ }^{14} \mathrm{C}$-label following PFA preservation of sorted cells (Silver \& Davoll 1978). Finally, we did not account for potential contributions to ${ }^{14} \mathrm{C}$ assimilation by picoplankton with low or no pigmentation that would not be quantitatively captured by the flow sorting methodologies but could contribute to filter-based estimates of production. In a study in the North Atlantic, Jardillier et al. (2010) sorted ${ }^{14} \mathrm{C}$-labeled nucleic acid-stained PPE (inclusive of both pigmented and non-pigmented cells) and found rates of production nearly equivalent to filterbased measurements. Thus, it is possible that measuring group-specific rates of ${ }^{14} \mathrm{C}$ assimilation by both pigmented and non- or low-pigmented cells (including mixotrophic or heterotrophic PPE, and particulate detritus) would have minimized the discrepancy between the ${ }^{14} \mathrm{C}$ assimilated by the sum of sorted cells and that caught on the picophytoplankton filter size fraction.

In summary, our examination of size-fractionated, group-, and cell-specific rates of carbon fixation and estimated picophytoplankton biomass over a period of $1 \mathrm{yr}$ at Station ALOHA revealed large variations in picophytoplankton production both vertically through the euphotic zone and over time. Collectively with measurements of cell abundance and derived biomass, these results highlight that time-resolved sampling of group-specific productivity and estimated biomass yields important new information on vertical and temporal patterns in the coupling between productivity and removal processes, providing further insights into the role of picophytoplankton in oceanic carbon cycling.

Acknowledgements. We are grateful to the HOT program science team for the collection and analyses of data used in this study. Sam Wilson and Jessica Fitzsimmons served as chief and junior chief scientists for the HOE-DYLAN V expedition. Thanks also to Ken Doggett and Karin Björkman for the technical support and advice on the flow sorting methodology, and to Christopher Schvarcz and Oscar Sosa for the use of picophytoplankton cultures for the flow cytometer size calibration. We acknowledge the captains and crew of the various research vessels that have supported the HOT program, including the University of Hawai'i vessels RV 'Kilo Moana' and RV 'Ka'imikai-OKanaloa.' Support for this work derived from US National Science Foundation grants OCE-1241263 (M.J.C.) and OCE1260164 (M.J.C. and D.M.K.), C-MORE (EF-0424599; D.M.K.), Gordon and Betty Moore Foundation grant no. 3794 (D.M.K.), the Simons Collaboration on Ocean Processes and Ecology (SCOPE award ID 329108; D.M.K. and M.J.C.), and the University of Hawai'i Denise B. Evans Research Fellowship in Oceanography (Y.M.R.).

\section{LITERATURE CITED}

Agawin NSR, Duarte CM, Agusti S (2000) Nutrient and temperature control of the contribution of picoplankton to phytoplankton biomass and production. Limnol Oceanogr 45:591-600

Agusti S, Satta MP, Mura MP (1998) Dissolved esterase activity as a tracer of phytoplankton lysis: evidence of high phytoplankton lysis rates in the northwestern Mediterranean. Limnol Oceanogr 43:1836-1849

Barone B, Bidigare RR, Church MJ, Karl DM, Letelier RM, White AE (2015) Particle distributions and dynamics in the euphotic zone of the North Pacific Subtropical Gyre. J Geophys Res Oceans 120:3229-3247

* Bec B, Husseini-Ratrema J, Collos Y, Souchu P, Vaquer A (2005) Phytoplankton seasonal dynamics in a Mediterranean coastal lagoon: emphasis on the picoeukaryote community. J Plankton Res 27:881-894

* Bertilsson S, Berglund O, Karl DM, Chisholm SW (2003) Elemental composition of marine Prochlorococcus and Synechococcus: implications for the ecological stoichiometry of the sea. Limnol Oceanogr 48:1721-1731

* Berube PM, Biller SJ, Kent AG, Berta-Thompson JW and others (2015) Physiology and evolution of nitrate acquisition in Prochlorococcus. ISME J 9:1195-1207

* Berube PM, Coe A, Roggensack SE, Chisholm SW (2016) Temporal dynamics of Prochlorococcus cells with the potential for nitrate assimilation in the subtropical Atlantic and Pacific oceans. Limnol Oceanogr 61:482-495

Bidigare RR, Van Heukelem L, Trees CC (2005) Analysis of algal pigments by high-performance liquid chromatography. In: Andersen RA (ed) Algal culturing techniques. Academic Press, New York, NY, p 327-345

* Björkman KM, Church MJ, Doggett JK, Karl DM (2015) Differential assimilation of inorganic carbon and leucine by Prochlorococcus in the oligotrophic North Pacific Subtropical Gyre. Front Microbiol 6:1401

Böttjer D, Dore JE, Karl DM, Letelier RM and others (2016) Temporal variability of nitrogen fixation and particulate nitrogen export at Station ALOHA. Limnol Oceanogr (in press), doi:10.1002/lno.10386

*Bainerd KE, Gregg MC (1995) Surface mixed and mixing layer depths. Deep-Sea Res I 42:1521-1543

* Brown SL, Landry M, Barber RT, Campbell L, Garrison D, Gowing M (1999) Picophytoplankton dynamics and production in the Arabian Sea during the 1995 Southwest Monsoon. Deep-Sea Res II 46:1745-1768

Brunet C, Johnsen G, Lavaud J, Roy S (2011) Pigments and photoacclimation processes. In: Roy $\mathrm{S}$, Llewellyn CA, Egeland ES, Johnsen G (eds) Phytoplankton pigments: characterization, chemotaxonomy and applications in 
oceanography. Cambridge University Press, New York, NY, p 445-471

Buitenhuis ET, Li W, Vaulot D, Lomas MW and others (2012) Picophytoplankton biomass distribution in the global ocean. Earth Syst Sci Data 4:37-46

Campbell L, Vaulot D (1993) Photosynthetic picoplankton community structure in the subtropical North Pacific Ocean near Hawaii (station ALOHA). Deep-Sea Res I 40: 2043-2060

Campbell L, Nolla HA, Vaulot D (1994) The importance of Prochlorococcus to community structure in the central North Pacific Ocean. Limnol Oceanogr 39:954-961

Caron DA (2000) Symbiosis and mixotrophy among pelagic microorganisms. In: Kirchman DL (ed) Microbial ecology of the oceans. Wiley, Hoboken, NJ, p 495-523

Carr ME, Friedrichs MAM, Schmeltz M, Noguchi Aita M and others (2006) A comparison of global estimates of marine primary production from ocean color. Deep-Sea Res II 53:741-770

Casey JR, Lomas MW, Mandecki J, Walker DE (2007) Prochlorococcus contributes to new production in the Sargasso Sea deep chlorophyll maximum. Geophys Res Lett 34:L10604

*asey JR, Aucan JP, Goldberg SR, Lomas MW (2013) Changes in partitioning of carbon amongst photosynthetic pico- and nano-plankton groups in the Sargasso Sea in response to changes in the North Atlantic Oscillation. Deep-Sea Res II 93:58-70

Chisholm SW (1992) Phytoplankton size. In: Falkowski PG, Woodhead AD (eds) Primary productivity and biogeochemical cycles in the sea. Plenum Press, New York, NY, p 213-237

* Church MJ, Ducklow HW, Karl DM (2004) Light dependence of $\left[{ }^{3} \mathrm{H}\right]$ leucine incorporation in the oligotrophic North Pacific Ocean. Appl Environ Microbiol 70:4079-4087

* Church MJ, Mahaffey C, Letelier RM, Lukas R, Zehr JP, Karl DM (2009) Physical forcing of nitrogen fixation and diazotroph community structure in the North Pacific subtropical gyre. Global Biogeochem Cycles 23:GB2020

Claustre H, Bricaud A, Babin M, Bruyant F and others (2002) Diel variations in Prochlorococcus optical properties. Limnol Oceanogr 47:1637-1647

Cochlan WP, Wikner J, Steward GF, Smith DC, Azam F (1993) Spatial distribution of viruses, bacteria and chlorophyll $a$ in neritic, oceanic and estuarine environments. Mar Ecol Prog Ser 92:77-87

* Dimier C, Giovanni S, Ferdinando T, Brunet C (2009) Comparative ecophysiology of the xanthophyll cycle in six marine phytoplanktonic species. Protist 160:397-411

* Dore JE, Karl DM (1996) Nitrification in the euphotic zone as a source for nitrite, nitrate, and nitrous oxide at Station ALOHA. Limnol Oceanogr 41:1619-1628

Dore JE, Letelier RM, Church MJ, Lukas R, Karl DM (2008) Summer phytoplankton blooms in the oligotrophic North Pacific Subtropical Gyre: historical perspective and recent observations. Prog Oceanogr 76:2-38

DuRand MD, Olson RJ, Chisholm SW (2001) Phytoplankton population dynamics at the Bermuda Atlantic Timeseries station in the Sargasso Sea. Deep-Sea Res II 48: 1983-2003

Eppley RW, Reid FMH, Strickland JDH (1970) Estimates of phytoplankton crop size, growth rate and primary production off La Jolla, CA in the period April through September 1967. Bull Scripps Inst Oceanogr Univ Calif $17: 33-42$
Eppley RW, Renger H, Venrick L, Mullin M (1973) A study of phytoplankton dynamics and nutrient cycling in the central gyre of the North Pacific Ocean. Limnol Oceanogr 18:534-551

*Fawcett SE, Lomas MW, Casey JR, Ward BB, Sigman DM (2011) Assimilation of upwelled nitrate by small eukaryotes in the Sargasso Sea. Nat Geosci 4:717-722

* Fawcett SE, Lomas MW, Ward BB, Sigman DM (2014) The counterintuitive effect of summer-to-fall mixed layer deepening on eukaryotic new production in the Sargasso Sea. Global Biogeochem Cycles 28:86-102

* Ferris JM, Christian R (1991) Aquatic primary production in relation to microalgal responses to changing light: a review. Aquat Sci 53:187-217

* Garside C (1982) A chemiluminescent technique for the determination of nanomolar concentrations of nitrate and nitrite in seawater. Mar Chem 11:159-167

* Glover HE, Prezelin BB, Campbell L, Campbell M (1988) A nitrate-dependent Synechococcus bloom in surface Sargasso Sea water. Nature 331:161-163

* Glover HE, Garside C, Trees CC (2007) Physiological responses of Sargasso Sea picoplankton to nanomolar nitrate perturbations. J Plankton Res 29:263-274

Goericke R, Welschmeyer NA (1993) The marine prochlorophyte Prochlorococcus contributes significantly to phytoplankton biomass and primary production in the Sargasso Sea. Deep-Sea Res I 40:2283-2294

*Heldal M, Scanlan DJ, Norland S, Thingstad F, Mann $\mathrm{NH}$ (2003) Elemental composition of single cells of various strains of marine Prochlorococcus and Synechococcus using X-ray microanalysis. Limnol Oceanogr 48: 1732-1743

Hollander M, Wolfe DA (1973) Nonparametric statistical procedures. Wiley, New York, NY

Jardillier L, Zubkov MV, Pearman J, Scanlan DJ (2010) Significant $\mathrm{CO}_{2}$ fixation by small prymnesiophytes in the subtropical and tropical northeast Atlantic Ocean. ISME J 4:1180-1192

Johnson KS, Riser SC, Karl DM (2010) Nitrate supply from deep to near-surface waters of the North Pacific subtropical gyre. Nature 465:1062-1065

Karl DM (2002) Nutrient dynamics in the deep blue sea. Trends Microbiol 10:410-418

KKarl DM, Church MJ (2014) Microbial oceanography and the Hawaii Ocean Time-series programme. Nat Rev Microbiol 12:699-713

KKarl DM, Lukas R (1996) The Hawaii Ocean Time-series (HOT) program: background, rationale and field implementation. Deep-Sea Res II 43:129-156

KKarl DM, Letelier R, Tupas L, Dore JE, Christian J, Hebel D (1997) The role of nitrogen fixation in biogeochemical cycling in the subtropical North Pacific Ocean. Nature 388:533-538

Karl DM, Church MJ, Dore JE, Letelier R, Mahaffey C (2012) Predictable and efficient carbon sequestration in the North Pacific Ocean supported by symbiotic nitrogen fixation. Proc Natl Acad Sci USA 109:1842-1849

* Letelier R, Karl DM, Abbott MR, Bidigare RR (2004) Light driven seasonal patterns of chlorophyll and nitrate in the lower euphotic zone of the North Pacific Subtropical Gyre. Limnol Oceanogr 49:508-519

Li WKW (1994) Primary production of prochlorophytes, cyanobacteria, and eukaryotic ultraphytoplankton: measurements from flow cytometric sorting. Limnol Oceanogr 39: 169-175 
Li B, Karl DM, Letelier RM, Church MJ (2011) Sizedependent photosynthetic variability in the North Pacific Subtropical Gyre. Mar Ecol Prog Ser 440:27-40

Liu H, Campbell L, Landry MR (1995) Growth and mortality rates of Prochlorococcus and Synechococcus measured with a selective inhibitor technique. Mar Ecol Prog Ser 116:277-287

Marañón E, Holligan PM, Barciela R, González N, Mouriño B, Pazó MJ, Varela M (2001) Patterns of phytoplankton size structure and productivity in contrasting open-ocean environments. Mar Ecol Prog Ser 216:43-56

Martiny AC, Kathuria S, Berube PM (2009) Widespread metabolic potential for nitrite and nitrate assimilation among Prochlorococcus ecotypes. Proc Natl Acad Sci USA 106:10787-10792

Moore LR, Goericke R, Chisholm SW (1995) Comparative physiology of Synechococcus and Prochlorococcus: influence of light and temperature on growth, pigments, fluorescence and absorptive properties. Mar Ecol Prog Ser 116:259-275

Moore LR, Post AF, Rocap G, Chisholm SW (2002) Utilization of different nitrogen sources by marine cyanobacteria. Limnol Oceanogr 47:989-996

Painter SC, Patey MD, Tarran GA, Torres-Valdés S (2014) Picoeukaryote distribution in relation to nitrate uptake in the oceanic nitracline. Aquat Microb Ecol 72:195-213

* Pinckney JL, Millie DF, Howe KE, Paerl HW, Hurley JP (1996) Flow scintillation counting of ${ }^{14} \mathrm{C}$-labeled microalgal photosynthetic pigments. J Plankton Res 18: 1867-1880

Raven JA (1986) Physiological consequences of extremely small size for autotrophic organisms in the sea. Can Bull Fish Aquat Sci 214:1-70

Raven JA (1998) Small is beautiful: the picophytoplankton. Funct Ecol 12:503-513

Reckermann M, Veldhuis MJW (1997) Trophic interactions between picophytoplankton and micro- and nanozooplankton in the western Arabian Sea during the NE monsoon 1993. Aquat Microb Ecol 12:263-273

Ribalet F, Swalwell J, Clayton S, Jiménez V and others (2015) Light-driven synchrony of Prochlorococcus growth and mortality in the subtropical Pacific gyre. Proc Natl Acad Sci USA 112:8008-8012

Rii YM, Duhamel S, Bidigare RR, Karl DM, Repeta DJ, Church MJ (2016) Diversity and productivity of photosynthetic picoeukaryotes in biogeochemically distinct regions of the South East Pacific Ocean. Limnol Oceanogr 61:806-824

Rocap G, Larimer FW, Lamerdin J, Malfatti S and others (2003) Genome divergence in two Prochlorococcus ecotypes reflects oceanic niche differentiation. Nature 424 : 1042-1047

Royston JP (1982) An extension of Shapiro and Wilk's W test for normality to large samples. Appl Stat 31:115-124
Shalapyonok A, Olson RJ, Shalapyonok LS (2001) Arabian Sea phytoplankton during Southwest and Northeast Monsoons 1995: composition, size structure and biomass from individual cell properties measured by flow cytometry. Deep-Sea Res II 48:1231-1261

* Sieburth JM, Smetacek V, Lenz J (1978) Pelagic ecosystem structure: heterotrophic compartments of the plankton and their relationship to plankton size fractions. Limnol Oceanogr 23:1256-1263

* Siegel DA, Doney SC, Yoder JA (2002) The North Atlantic spring phytoplankton bloom and Sverdrup's critical depth hypothesis. Science 296:730-733

Sieracki ME, Verity PG, Stoecker DK (1993) Plankton community response to sequential silicate and nitrate depletion during the 1989 North Atlantic spring bloom. Deep-Sea Res II 40:213-225

Silver MW, Davoll PJ (1978) Loss of ${ }^{14} \mathrm{C}$ activity after chemical fixation of phytoplankton: error source for autoradiography and other productivity measurements. Limnol Oceanogr 23:362-368

Steemann Nielsen E (1952) The use of radioactive carbon $\left({ }^{14} \mathrm{C}\right)$ for measuring organic production in the sea. J Cons Int Explor Mer 18:117-140

Sverdrup HU, Johnson MW, Fleming RH (1946) The oceans: their physics, chemistry and general biology. PrenticeHall, New York, NY

* Takahashi M, Bienfang PK (1983) Size structure of phytoplankton biomass and photosynthesis in subtropical Hawaiian waters. Mar Biol 76:203-211

* Treibergs LA, Fawcett SE, Lomas MW, Sigman DM (2014) Nitrogen isotopic response of prokaryotic and eukaryotic phytoplankton to nitrate availability in Sargasso Sea surface waters. Limnol Oceanogr 59:972-985

Vaulot D, Marie D, Olson RJ, Chisholm SW (1995) Growth of Prochlorococcus, a photosynthetic prokaryote, in the Equatorial Pacific Ocean. Science 268:1480-1482

Viviani DA, Karl DM, Chuch MJ (2015) Variability in photosynthetic production of dissolved and particulate organic carbon in the North Pacific Subtropical Gyre. Front Mar Sci $2: 73$

Welch BL (1951) On the comparison of several mean values: an alternative approach. Biometrika 38:330-336

White AE, Letelier RM, Whitmire AL, Barone B, Bidigare RR, Church MJ, Karl DM (2015) Phenology of particle size distributions and primary productivity in the North Pacific subtropical gyre (Station ALOHA). J Geophys Res Oceans 120:7381-7399

*Worden A, Nolan J, Palenik B (2004) Assessing the dynamics and ecology of marine picophytoplankton: the importance of the eukaryotic component. Limnol Oceanogr 49: 168-179

Zubkov MV, Tarran GA (2008) High bacterivory by the smallest phytoplankton in the North Atlantic Ocean. Nature 455:224-226 


\section{APPENDIX}

Table A1. Cultivated isolates used to determine empirical relationships with the forward scatter (FSC) signal of the flow cytometer. Cell diameters were estimated using epifluorescence microscopy. FSC was linearly normalized to the 1 mm beads run concurrently with the phytoplankton isolates. Values are mean $\pm \mathrm{SD}$

\begin{tabular}{|lcr|}
\hline Culture and environmental isolates & Estimated diameter $(\mu \mathrm{m})$ & FSC \\
\hline Prochlorococcus spp. (MIT 9301) & $0.5 \pm 0.1$ & $5.2 \pm 2.1$ \\
Micromonas sp. (KB-FL13) & $1.5 \pm 0.2$ & $389 \pm 115$ \\
Raphidophyte (KB-FL10) & $2.2 \pm 0.2$ & $1237 \pm 282$ \\
Pelagomonas spp. (AL-DI01-P) & $2.5 \pm 0.5$ & $2085 \pm 833$ \\
Chlorarachniophyte (AL-FL05) & $2.9 \pm 0.4$ & $2220 \pm 121$ \\
Chrysochromulina sp. (AL-TEMP-12) & $3.2 \pm 0.1$ & $2199 \pm 99$ \\
Derived equation & Cell diameter $(\mu \mathrm{m})=0.3071 \times(\mathrm{FSC})$ & 0.2857 \\
$\mathrm{R}^{2}$ & 0.99 & \\
\hline
\end{tabular}

Table A2. Mean \pm SD of cell diameter $(\mu \mathrm{m})$, cell volume $\left(\mu \mathrm{m}^{3}\right)$, and cell carbon biomass (fg C cell ${ }^{-1}$ ) of Prochlorococcus $(\mathrm{PRO})$, Synechococcus (SYN), and photosynthetic picoeukaryotes (PPE). For cell diameters, means were obtained by averaging across samples taken throughout the year and across designated depths, and SDs were calculated using the \% CV of the forward scatter signal measured with the FlowJo software. For the other measurements, means and SDs were obtained by averaging across all samples

\begin{tabular}{|c|c|c|c|c|c|c|}
\hline & $\begin{array}{l}\text { Diameter } \\
\text { at } 0-125 \mathrm{~m}\end{array}$ & $\begin{array}{l}\text { Diameter } \\
\text { at } 0-45 \mathrm{~m}\end{array}$ & $\begin{array}{c}\text { Diameter } \\
\text { at } 75-125 \mathrm{~m}\end{array}$ & $\begin{array}{c}\text { Cell spherical } \\
\text { volume }\end{array}$ & $\begin{array}{c}\text { Cell C } \\
\text { biomass }^{\mathrm{a}}\end{array}$ & $\begin{array}{c}\text { Cell C } \\
\text { biomass }^{\mathrm{b}}\end{array}$ \\
\hline PRO & $0.4 \pm 0.3$ & $0.4 \pm 0.2$ & $0.4 \pm 0.3$ & $0.04 \pm 0.03$ & $9 \pm 8$ & $12 \pm 9$ \\
\hline SYN & $0.7 \pm 0.4$ & $0.6 \pm 0.4$ & $0.7 \pm 0.4$ & $0.18 \pm 0.11$ & $43 \pm 26$ & $50 \pm 29$ \\
\hline PPE & $1.5 \pm 1.1$ & $1.6 \pm 1.1$ & $1.5 \pm 1.1$ & $1.9 \pm 0.5$ & $445 \pm 108$ & $453 \pm 104$ \\
\hline
\end{tabular}

Editorial responsibility: Graham Savidge, Portaferry, UK
Submitted: May 26, 2015; Accepted: October 26, 2016

Proofs received from author(s): December 19, 2016 